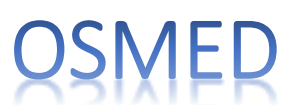

e-ISSN 2458-9519
Osmanlı Medeniyeti Araştırmaları Dergisi

Journal of Ottoman Civilization Studies

Cilt 5, Sayı 8, Nisan 2019 \& Vol 5, No 8, April 2019

(C) 2018 Telif Hakkı OSMED'e aittir

DOI: $10.21021 /$ osmed.486022

Makale Türü: Araştırma Makalesi

Article Types: Research Article

Geliş Tarihi \& Received: 11.20.2018

Kabul Tarihi \& Accepted: 30.01.2019

OSMED, 2019, 5(8): $1-23$

\title{
XIX. Yüzyıl Osmanlı Şehir Silüeti: Şam Örneği
}

\author{
XIX. Century Ottoman City Skyline: Damascus Example
}

\section{Osman Cengiz*}

\section{$\ddot{\mathbf{O z}}$}

Şam, yüzyıllar boyunca pek çok yıkım ve imar görmüştür. Bu makale şehrin XIX. asırda kaydettiği tarihsel sürece ilişkin bir panorama sunmayı hedeflemektedir. Bu şehir portresi aynı zamanda bir Osmanlı şehri olan Şam'ın politik, sosyal ve ekonomik tarihinin ilgili süreçteki durumunu da aksettirecektir. Şam'da XIX. yüzyıl boyunca tarım, sanayi ve ticaret gibi iktisadi faaliyetler icra edilmekte fakat bunlar arasında ağırlığı ticaret oluşturmaktaydı. Tarım için kullanılan tek su kaynağı şehrin içinden geçen ve Altın Nehir denilen Baradâ Nehri'ydi. Şehrin hac güzergahında yer alması şüphesiz ki onun gelişmesinde etkili olmuştu. Şam'ın sosyokültürel yapısı XIX. yüzyıl için birçok sıkıntı ve ayrılıklara sahne olmuş, vaktiyle kültürel bir zenginlik adına bir arada yaşayan farklı kimlikler, sermayeci aktörlerin elinde bir savaş silahı haline gelmişti.

Anahtar Kelimeler: Şam, Dimaşk, Osmanlı Şehri, Misyonerlik, Milliyetçilik

\begin{abstract}
Damascus has seen many demolitions and zoning for centuries. This article is based on the city's XIX. century aims to present a panorama of the historical process. This city portrait will also reflect the political, social and economic history of the Ottoman city of Damascus. During the XIX century, such as industry and agricultural activities are carried out in economic activities, but among them was the weight of trade in Damascus. The only source of water used for agriculture was through the city and the Golden river called Baradâ. The city's location on the pilgrimage route had undoubtedly been instrumental in its development. The socio-cultural structure of Damascus has witnessed many hardships and separations for the XIX century, and different identities, which once lived together for a cultural wealth, became a weapon of war in the hands of capitalist actors.
\end{abstract}

Keywords: Sham, Damascus, Ottoman City, Nationalism, Missionary

*(Dr); cengiz.osman@hotmail.com; ORCID:orcid.org/0000-0001-8143-5388

Kaynak Gösterme: Cengiz, O . "XIX. Yüzyıl Osmanlı Şehir Silüeti: Şam Örneği". Osmanlı Medeniyeti Araştırmaları Dergisi 5 (2019): 1-23. 


\title{
Giriș: İdarî ve İmarî Panaroma
}

\author{
"Sokaklar dar ve girift ama Kahire'dekilerden çok daha az... \\ Sokaklarda sadece, karanlık ve kasvetli bir görünüşe sahip mesken-evler var. \\ Birkaç evin sokağa bakan penceresi yok. Olanlar da sıkı ahşap kafeslerle kaplanmış. \\ Pazarlara ve halkın diğer uğrak yerlerine yaklaşıncaya kadar bütün şehir, \\ tuhaf ve gizemli bir sükûtla kuşatılmış görünüyor." KINNEAR (1841: 279)
}

Romalıların, Perslerin ve Arapların efsanelerini yüzyıllardır isminin üzerinde bir mühür gibi taşıyan Dımaşk ${ }^{1}$ çok kültürlülük coğrafyası Bilâdüşşâm (Şam ülkeleri: Suriye, Filistin, Lübnan ve Ürdün) bölgesinin bağrında atan kalbiydi. Bereketli Hilal'in güney-batı kolunda yer alan şehir, sonraki ismiyle "Şam"; 1521 yılından itibaren kesin olarak Osmanlı hâkimiyetine bağlanmış ve bu hukukî bağlılık 1 Ekim 1918'de İngiliz ordusuna bağlı Avustralya birlikleri tarafından işgal edilip, Mart 1920'de Faysal'ın krallığı altında başşehir olarak bağımsız Suriye devleti şemsiyesine girinceye kadar sürmüştür. ${ }^{2}$

Bir yeryüzü cenneti olarak tasvir edilen kentin, ${ }^{3}$ XIII. yüzyıl Moğol, XV. yüzyıl Timur istilalarıyla, bu yüzyıllar öncesinde kazandığı imar ve refah varlığı sekteye uğramış; XVII. yüzyılın hemen başında Canbolatoğlu Ali tarafından muhasara altına alınıp kenar mahalleleri yağmalanmış, kısacası bahsi geçen asırlarda Şam, güzelliğinden çok şey kaybetmişti. XIX. yüzyıl da kent için çalkantılı ve sancılı bir zaman dilimi olacaktır.

Şam'ın tarih boyunca ilgi görmesi, hatta Ortadoğu'nun idarî merkezlerinden olmas1, antik dönemden itibaren "Beyrut hinterlandı" ve İslam fetihleri sonrası "hac güzergâhı" gibi ticarî-dinî kavramlarla veya bunların türevleri olan başkaca sebeplerle açıklanabilirdi. Geçmişten gelen bu idarî merkez olma geleneği kenti zenginleşmeye ve büyümeye hazır hale getirmiş, bu sayede çeşitli siyasi ve sosyal hadiseler akabinde çabuk toparlanmayı başarmıştır. XIX. yüzyılın son çeyreğinde Şam sancağ $1{ }^{4}$ Hama ve Havran sancaklarıyla Suriye Vilayetinin ${ }^{5}$ merkezi durumundayd1. ${ }^{6}$ Şam' 'n idarî başkent, Halep'in ise ticarî başkent olarak öne çıktığı söylense $\mathrm{de}^{7}$ kentin, bölge ticaretine de liderlik ettiğini kaydetmeliyiz. ${ }^{8}$

\footnotetext{
${ }^{1}$ Kalkaşendî Ahmed b. Ali, Subhu'l-A'şâ fî Sınâati'l-Inşâ, Dâru'l-Fikr, Beyrut 1987 IV/95.

2 Şit Tufan Buzpınar, "Şam", Türkiye Diyanet Vakfı İslam Ansiklopedisi, İstanbul, 2010, XXXVIII/311-319. Şehir, Antilübnan (Cebelüşarkî) dağlarının doğu eteklerindeki Kâsiyûn dağı ile Badiyetüşşâm adı verilen çöl sahası arasındaki vahada (Gûta Vahası) kurulmuştur.

${ }^{3}$ R. Hartmann "Şam", MEB İslam Ansiklopedisi, Eskişehir, 2001, XI/300.

4 Bu dönemde Şam sancağı -Şam, Dumanik (Duma), Vadilacem, Hasba, Raşya, Baalebek ve Bekâülaziz kazalarından oluşmaktadır. Binbaşı Mustafa Rasim, Memâlik-i Mahrûsa-i Şâhâne Coğrafyası, Dersaâdet, Tophane-i Âmire Mat. 1305, 266. Beyrut Vilayeti kazaları ise Beyrut, Lazikiye, Trabluşşam, Akka ve Belkâ'dır. Age. s. 269

${ }^{5}$ Bu satırları referans gösterdiğim eser, bir ders kitabı olup 1864 Vilayet nizamnamesinden sonra (1305/1889 senesinde) Mühandishane-i Berr-i Hümayûn ve Hendese-i Mülkiye Mektebi için telif edilmiştir.

6 Mustafa Rasim Memâlik-i Mahrûsa-i Şâhâne Coğrafyası, 265.

${ }^{7}$ Nelly Hanna, "Osmanlı Dönemi Arap Şehir Tarihi Üzerine Bir İnceleme” Türk Şehir Tarihi, Türkiye Araştırmaları Literatür Dergisi, 2005, Cilt 3 Sayı 6, İstanbul, 106.

${ }^{8}$ Charles Issawi, The Fertile Crescent 1800-1914 A Documentary Economic History, Oxford Universty Press, New York, 1988, 159.
} 
Şehir portresinde ise yüzyıl içinde pek çok değişiklik meydana gelmişti. Bu değişikliklerin yansımalarını mevcut mimarî yapılardan takip etmek de mümkündür. ${ }^{9}$ XIX. asır, Tanzimât (1839) ve Islahat (1856) Fermanlarının yürürlüğe sokulduğu ve II. Mahmut (1808-1839), I. Abdülmecid (1839-1861), Abdülaziz (1861-1876) ve II. Abdülhamit (18761909) gibi her biri Devlet-i Aliyye'yi payandalayan yenilenme ve yeniden merkezîleşme temalı "reform ve nizamname seferberliği" takipçisi sultanların tahta geçtiği bir yüzyıl olmuştur. Şam 1831-1840 yılları arasında Mısır yönetimine bağlanmışsa da Kahire'nin idarî politikası, önceki dönemlerde olduğu gibi, Avrupa etkisindeki Beyrut-Yafa kıyı hattına değil daha çok Halep-Şam-Kudüs hinterlandına odaklanmıştır. ${ }^{10}$

Şehir, yaklaşık 130 hektarlık surlarla çevrili bir bölüm, sur içi üç mahalle, vahada geçimini tarımla sağlayan çok sayıda birbirine yakın köy ve kendisine iki kilometre kuzeybatıda Cebel-i Kâsiyûn eteklerinde kurulmuş Sâlihiyye yerleşiminden meydana gelmekteydi. Şehrin silüeti yüzyıllar içinde istila ve yangınlarla pek çok tahribata uğramış olmasına rağmen esasen hemen hiç değişmemiştir. ${ }^{11}$ Zengiler, Eyyûbiler ve Memlükler zamanında pek çok medrese, çarşı ve hanlarla mamur olmuş, Osmanl1-Türk devri ise şehrin imar tarihindeki mühim yerini almıştı. ${ }^{12}$ Klasik İslam şehirlerinin genel özellikleriyle uyumlu olarak zamanın örgütlenmesi mekandaki örgütlenmeye yansımış ve en çok vakit geçirilen Ulu $\mathrm{Cami}^{13}$ ve onun çevresini saran çarşılar bu kentte de merkezi planda yer almıştır.

Romalılarda, bir kale ve o kalenin etrafından geniş bir alanın surlarla çevrilmesiyle muhkem hale getirilmiş klasik feodal şehir anlayışını yansıtan kent, Eyyûbilerde Babü'sSağîr ile Bâbü Keysân arasında güneye; Babü'l-Ferec ile pazarlar mahallesi (Sûklar) arasından kuzeye ve Bâbü Câbiye'den de güney-batı istikametine doğru genişlemiştir. Salihiyye'de de zaman içinde belli oranda bir büyüme gözlenmektedir. ${ }^{14}$ Memlükler zamanında Yukarı Meydan Mahallesi, Kanavât ile Musallâ mahalleleri arası ve Saruca Pazarı'nda yeni yapılarla kent büyümüştür. Bu gelişim ve imar esasen, Kuzey Suriye, Havran, Filistin ve Hicaz'a giden büyük ticaret yollarının önemine bağlıydı.

Osmanlılar döneminde ise şehir, Havran'a giden güney-batı yolu istikametinde yani açıkça hac güzergâhı üzerinde gelişimini sürdürmüştür. Kentin doğu bölümünde bu yöne doğru gelişimi tıkayan Yahudî ve Hiristiyan mahallelerinin varlığı nedeniyle doğuya doğru hiç bir yayılma olmamıştır. Bu yüzden Büyük Cami [Emevî Camii] ile Düz [Müstakîm] Sokak arasındaki pazarlar mahallesi (kentin merkez hücresi) batı duvarı boyunca Saruca Sûku'nu Meydan'a bağlayan büyük sokağın biraz doğusuna kaymış ve merkezi konumunu

\footnotetext{
${ }^{9}$ Değişen zamanların ve anlayışın bir dışa vurumu olarak XIX. Yüzyıl Osmanlı Şam'ında sanat ve şehir kalkınmasının kısa bir değerlendirmesi için bkz. Stefan Weber, "Ottoman Damascus of the 19th Century Artistic and Urban Development as an Expression of Changing Times" Art Turc / Turkish Art 10th International Congress of Turkish Art. Geneva, 1999, 731-740.

${ }^{10}$ Yasemin Avcı, Değişim Sürecinde Bir Osmanlı Kenti: Kudüs (1890-1914), Phoenix Yayınevi, Ankara, 2004, 53.

${ }^{11}$ Hartmann "Şam", 307.

12 Hartmann"Şam", 306.

13 "Câmii Benî Ümeyye el-Kebîr", Ümeyye Câmii olarak da bilinir VI. Emevî hükümdarı I.Velid tarafından yaptııılmış 715 senesinde inşâsı bittiği yıl I. Velid ölmüştür. Cami, Şiiler ve Hıristiyanlar için de ziyaretgâhtır.

${ }^{14}$ Andre Raymond, Osmanlı Dönemi Arap Kentleri, Çev. Ali Berktay, , Tarih Vakfı Yurt Yayınları, İstanbul, 1995, 26. Krş. Ekler: şehir planları.
} 
korumuştur. ${ }^{15}$ XIX. yüzyıldaki batıya doğru bir milden fazla, güneye doğru ise iki mil olarak gerçekleşen genişlemeyle birlikte kenar mahalleler de şehre katılmış böylece şehir, meydan ile mahallelerden oluşan düalist bir yapı kazanmıştır. ${ }^{16}$ Raymond'ın ifadesiyle de idari binaların ve kültürel yapıların, kalenin batısına yerleştirilmeleri Şam'ın bu göreceli “yeniden merkezîleşmesine" katkıda bulunmuştur. ${ }^{17}$

Kentte 45 çarş1, ${ }^{18} 57$ han, ${ }^{19}$ (1871'de) 6.606 dükkan ${ }^{20}$ vardı. Hanlar, üstü açık merkezi mekanlarıyla geleneksel yapıyı sürdürmüș olsa da kubbelerle örtülü yapılar da az değildi. ${ }^{21}$ Bâbü'l-Hadîd'in yakınındaki Rum Pazarı (The market of the Greeks) buraya gelen her seyyah tarafından ziyaret edilen kentin en renkli pazarlarındandı. Burada, Şam kılıçları ve hançerleri, gümüş altın ve değerli taşlarla süslenmiş her çeşit silah, İran halıları, Keşmir ve Hint şalları satılmaktaydı. ${ }^{22}$ Kuyumcular çarşısı merkez camiye bitişikti. ${ }^{23}$ Kalenin hemen güneyinde II. Abdülhamid tarafından yaptırılan Hamidiye Çarşısı, doğuya doğru Rum Pazarı'nın devamı gibiydi. Bakırcılar fütüvvetinin, kulakları sağır eden gürültüsünü saraçların eyer ve askerî koşu takımları imal ederken çıkardıkları sesler takip ediyordu. Şehirdeki han gibi yapılarda Saracenic mimarî belirgindi. ${ }^{24}$ Bütün tecrübeli ve sağlam tüccarların büyük hanlarda veya kervansaraylarda depoları vardı. Ayrıca eşek ve deve pazarları Baradâ'nın kuzey yakasında ve merkezden biraz uzakta konumlanmıştı.

Kinnear'ın ifadesiyle 1839 'da Şam sokaklarında yürüyen bir kişi pazarlarda satış için sergilenen malların parlak renkleri ve aşırı çeşitliliği sebebiyle şaşkına dönebilirdi. Buralardan gelip geçen insanların üzerinde, şark kıyafetlerinin bütün çeşitlerini görmek mümkündü. ${ }^{25}$ Zaten doğunun tüm kentleri arasında Şam belki de en doğulu olanı, çok az değişime uğramış bir kentti. Avrupa giysilerini görmek çok ender görülüyor; birkaç istisna dışında Frenklerin de Suriye giysilerini benimsemiş oldukları müşahede ediliyordu. ${ }^{26}$

\footnotetext{
${ }^{15}$ Raymond Osmanlı Dönemi Arap Kentleri, 147. Ayrıca krş. Şekil-5 Şam şehir planı mavi kısımlar.

16 J.L. Porter- A.M.,F.R.S.L., Five Years in Damascus of the History, Topography and Antiquities of That City, Vol. II, London, 1855, I/44-45.

${ }^{17}$ Raymond, Age, 147.

18 Raymond, Age, 174.

${ }^{19}$ Raymond, Age, 166, 176.

${ }^{20}$ Raymond, Age, 169. 1871'deki sayıdır.

${ }^{21}$ Raymond, Age, 181.

22 Porter Five Years in Damascus of the History, Topography and Antiquities of That City, 1/50. Şehri 1839'da ziyaret eden Kinnear, Cairo, Petra and Damascus in 1839, ise heybetli Şam kılıçlarının artık yapılmadığını ancak hakiki Şam hançerinin çok yüksek fiyattan olmak şartıyla satıldığına bazen rastladığını kaydeder. Ayrıca, bazı varlıklı evlerde görülen, altınla işlenmiş muhteşem Şam ipeğini de pazarlarda kolay bulunmadığını, artık imal edilmediğini tahmin ettiğini kaydeder. John Gardiner Kinnear, Cairo, Petra and Damascus in 1839, , Cairo, Petra and Damascus in 1839, John Murray, Albemarle Street, London 1841, 281.

${ }^{23}$ Raymond, Osmanlı Dönemi Arap Kentleri, 162.

${ }^{24}$ Kinnear, Cairo, Petra and Damascus in 1839, 281. "Saracen: Devlet-i Emeviyye ve Abbâsiyye ve Fâtımiyye vaktinin Arab Müslimi ki ya şarkıyyûn lafzından ve yahud istihkâran sârıkîn lafzından muharrefdir. Saracenic: Eski Arap Müslimînine mensub ve müteallik." W. James Redhouse, A Lexicon English and Turkish / Lehcetü'lMeânî, Print: A.H. Boyajian, Third Edition, Constantinople, 1884, 661.

${ }^{25}$ Kinnear, Cairo, Petra and Damascus in 1839, 280.

${ }^{26}$ Eyüp, Özveren, "Beyrut" Keyder, Özveren, Quataert (Ed.) Doğu Akdeniz'de Liman Kentleri,Tarih Vakfı Yurt Yayınları, İstanbul, 1994, 77.
} 
Bununla birlikte pek çok evde Avrupa iskemle ve sandalyeleri atabe ${ }^{27}$ boyunca yerleştirilmişti. ${ }^{28} 500$ Yard (1 yard: 91,44 cm) hatta daha fazla devam eden Müstakîm Sokak $^{29}$ üzerinde, modern tarzda inşa edilmiş St. Mary Rum Kilisesi vardı. ${ }^{30}$

Şehrin 1880'lerdeki bir gece tasviri, Mrs. Mackintosh tarafından şöyle yapılmaktadır.

"Şehrin geceleri, karanlık ve kasvetliydi. Pazarlar, ya çok sık ya da birbirinden çok uzak yerleştirilmiş donuk ve fersiz kü̧̈ük kandillerle aydinlatillyordu. Pazarlar dişında şehrin geri kalanı, geceleri neredeyse tamamen karanlı̆̆a gömülüyordu. Hiç kimseye -tutuklanma eziyeti söz konusu olduğundan- fener taşımadan sokağa çıkma izni verilmiyordu. Zenginlerin, renkli cam parçalarıyla süslenmiş ve parafin yağ veya iki kandille aydınlatılmış bazen Londra'daki sokak lambalarına benzeyen büyük fenerleri, onların hemen önlerinden taşınıyordu. Fakirler ise küçük el fenerleri taşıyorlardı."

\section{Paranın Yolculuğu ve Kutsalın Gölgesi}

Şamlılar XIX. yüzyılda tarım, sanayi ve ticaret gibi iktisadi faaliyetlerde bulunmakta fakat bunlar arasında ağırlığı ticaret oluşturmaktaydı. Tarım için kullanılan tek su kaynağı şehrin içinden geçen ve Altın Nehir denilen Baradâ Nehriydi. ${ }^{32}$ Baradâ zayıf debili (yıllık yaklaşık $10 \mathrm{~m}^{3}$ ) olmasına rağmen bu miktar, fazla yağış almayan bu bölgede kentin ve vahanın yaşamasını sağlıyordu. ${ }^{33}$ Nehir, dağlardan inerken üç kola ayrılıyor, ortadaki en geniş olanı doğrudan şehre akıyor, hamamları ve çeşmeleri destekliyordu. Bu kol, yer altı kanal şebekesiyle şehirdeki her bir eve su tedarikinde kullanılmaktayd. ${ }^{34}$

$\mathrm{Bu}$ su kanallarını temizlemek için sık sık yerleştirilmiş menfezler, toprağın üzerinde kanallar boyunca küçük toprak kümeleri oluşturmuştu. ${ }^{35}$ Nehrin iki yan kolu ise pek çok küçük kanala ayrılarak çevre bahçelerin sulanmasında kullanıldıktan sonra şehrin kuzeydoğusunda birleşmekteydi. ${ }^{36}$ İyi geliştirilmiş bir dağıtım sistemiyle suyu Şam'ın farklı dış mahallelerine taşıyan kanallar, mahallelerin, bol ve iyi bir içme suyuna kavuşmasını sağlıyordu. ${ }^{37} \mathrm{Bu}$ çok eski bir düzenlemeydi ${ }^{38}$ ve Osmanlılara sadece bakımıyla ilgilenmek

\footnotetext{
27 "Atabe", eşik. Burada kapı girişinden sonraki genişçe alçak eşik anlamında olup bir ya da iki adımla odanın zemine çıkılırdı. Bkz. Annie-Christine Daskalakis Mathews, "A Room of Splendor and Generosty from Ottoman Damascus", İnstitute of Arts, New York Universty, Metropolitan Museum Journal 32, 1997, s. 114 vd.

${ }^{28}$ Mackintosh, Damascus and Its People, Seely Jackson and Halliday, Fleet Street, London, 1883, 12.

29 Ingilizce metinlerde geçen "The Straight Street" ifadesi Ali Berktay tarafından Fransızca'dan "Düz Sokak" olarak tercüme edilmiştir. (Raymond, Osmanlı Dönemi Arap Kentleri, 147) Ben aslına uygun olarak "Müstakîm Sokak" demeyi tercih ettim. Bkz. Münir Baalbâkî-Rûhî Baalbâkî , Al-Mavrid Dictionary, English-Arabic-ArabicEnglish, Dâru'l-ilm Lilmalâyîn, Beyrut, 1998, 913.

30 Porter, Five Years in Damascus of the History, Topography and Antiquities of That City, 1/56.

${ }^{31}$ Mackintosh, Damascus and Its People,15.

32 Kinnear, Cairo, Petra and Damascus in 1839, 270.

33 Raymond, Osmanlı Dönemi Arap Kentleri, 108.

34 D.S. Margoliouth, Cairo, Jerusalem and Damascus: Three Chief Cities of the Egyptian Sultans, , Dodd, Mead and Company, New York 1907, 373.

35 Porter Five Years in Damascus of the History, Topography and Antiquities of That City, 1/159.

${ }^{36}$ Kinnear, Cairo, Petra and Damascus in 1839, 270.

37 Margoliouth, Cairo, Jerusalem and Damascus, 374.
} 
kaldı. Elinde bu amaçlarla kurulmuş önemli vakıf fonları bulunan kadı, bu işle uğraşıyordu; görevliler (şâvî) kanalların ve dağıtım şebekesinin denetiminden sorumluydular. ${ }^{39}$

Osmanlı İmparatorluğu'nun geniş sınırları ve bu sınırlar arasındaki ulaşım ağı, provizyonist (iâşeci) anlayış hariç tutulsa bile Devlet-i Aliyye dışına ihracatı teşvik edici bir yapıda değildi. Zira iç ticari hareketlilik -mesela Mısır ile İstanbul arasında- sektörün, çoğu mal ve hizmetlerini emiyor üretim fazlası olmayınca dış ticarete zaruret veya hedef bulunmuyordu. Ayrıntıya girmek gerekirse XVIII. yüzyılın ilk çeyreğine kadar Halep ile Şam kendilerine koyun, yün, yağ ve peynir, halı, deve, balmumu, tütün ve boya için mazi ${ }^{40}$ temin eden civardaki Türkmen ve Kürt aşiretleriyle rahatsız edici bir birliktelik içinde yaşamaktaydı. Aşiretler, karşıllı̆ında aldıkları kumaş, boya, silah, mücevher, kahve, şeker ve diğer şekerli yiyecekleri beraberlerinde Anadolu yaylasındaki yaz otlaklarına götürürlerdi. ${ }^{41}$ XIX. yüzyılın başından yüzyılın sonuna gelinceye kadar Suriye'nin ticareti yirmi kat arttı fakat, 1900'den sonra bu hız azald1. ${ }^{42}$ Suriye ve Filistin bölgesine liderlik eden bir ticaret şehri konumuna sahip olan $\operatorname{kentin}^{43}$ ekonomisinin güvenli bir şekilde gelişmesi ve yaşamasında kente ulaşan yollardaki derbentler de katkıda bulunmuş olmalıdır. Zira ticarî ve askerî yollar üzerinde son derece önemli noktalarda hemen her dönemde askerî kuvvetler kullanılıyor; Suriye'de Humus ile Şam arasında iki kapulu derbendinde mustahfizlar bulunuyordu. ${ }^{44}$

Şam ve Halep daha çok, kü̧̈ük iş yerlerinin toplandığı imalat merkezleriydi. ${ }^{45}$ XIX. yüzyılın ikinci çeyreğine doğru Şam'ın ithal ettiği başlıca mallar pamuk ürünleri, pamuk ipliği, demir donanımları (iron hardware), Batı Hindistan malları, çivit ve kırmızı boya (cochineal) idi. ${ }^{46}$ XIX. yüzyılın ortasında kumaş, çivit ve deri gibi Irak, Acem ve Hint mallarının Bağdat'tan Şam'a gelen kervanlarla getirildiği ifade edilmekle beraber ${ }^{47} \mathrm{John}$ Kinnear, Hindistan'dan İran körfezine getirilen ve Bağdat kervanlarıyla Şam'a dağıtılagelen pek çok malın 1839'da doğrudan Londra ve Liverpol'dan Beyrut'a ithal edildiğini kaydetmiştir. ${ }^{48}$ Yine aynı süreçte Şam'ın kendi imal ettiği ve Almanya ile İngiltere'den ithal

\footnotetext{
${ }^{38}$ Margoliouth, İslam öncesi döneme kadar uzandığını kaydederek eski ve yeni Şam tarihi yazarlarının farklı zamanlara ait 6 kanalın ismini verdikleri söyler bkz. Cairo, Jerusalem and Damascus, 373.

39 Raymond, Osmanlı Dönemi Arap Kentleri, 109.

${ }^{40}$ Boyacııık ve eczacıııkta kullanılan bir ağaçtır. Pamuk ve yün boyamak için yaprakları kaynatııırdı.

${ }^{41}$ Halil İnalcık, Osmanlı Imparatorluğunun Ekonomik ve Sosyal Tarihi, İstanbul, 2/815.

42 Inalcık, Osmanlı Imparatorluğunun Ekonomik ve Sosyal Tarihi, 2/949. Suriye'de 1825'te yıllık $90.000 \mathrm{~kg}$ saf yün üretilmekteyken 600.000 Roma Kilesi buğday harmanlanmaktaydı. Issawi, The Fertile Crescent 1800-1914, 78.

${ }^{43}$ Issawi The Fertile Crescent 1800-1914, 159.

${ }^{44}$ Cengiz Orhonlu, Osmanlı Imparatorluğunda Derbent Teşkilatı, Eren Yayıncılık, İstanbul, 1990, 62-63.

45 Inalcık, Osmanlı Imparatorluğunun Ekonomik ve Sosyal Tarihi, 2/1015.

${ }^{46}$ Kinnear, Cairo, Petra and Damascus in 1839, 282.

47 Inalcık, Osmanlı Imparatorluğunun Ekonomik ve Sosyal Tarihi, 2/938

${ }^{48}$ Kinnear, Cairo, Petra and Damascus in 1839, 282. "Many article which used to be brought from India to the Persian Gulf and reached Damascus by the caravans from Bagdad, are now [1839] imported direct from London and Liverpool to Beyrout."
} 
ettiği mensucatı da Bağdat'a ihraç ettiği; Şam'dan Bağdat'a giden kervan yılda 1000-1500 deve ile 250-350 ton eşya taşıdığı kaynaklarda yer almıştır. ${ }^{49}$

Beyrut, Şam'ın başlıca limanı olmakla birbirlerini tamamladıkları kadar aslında rekabet de ediyorlard1. ${ }^{50} 1840$ 'ların sonunda imparatorluğun 19 büyük ticaret şehrinde 80 İngiliz ve 70 Fransız ticarethanesi vardı. Şam'da ise 5 İngiliz şirketi ${ }^{51}$ ve Beredâ kenarında Fransızlara ait bir şirketin çalışma ofisi mevcuttu. ${ }^{52} 1855$ 'te imparatorluğun büyük şirket sayısı 20 iken 1895 'te 30 'a çıkt. ${ }^{53} 1871$ 'de Beyrut'ta 5 İngiliz firması olmasına rağmen aynı sene Şam ve Halep'te hiç biri kalmamıştı. ${ }^{54}$ Şirketlerin kapanması, 1861 olayları ve devam eden kargaşanın, ticareti menfî yönde etkilemesi neticesi olmalıdır. İngiltere, XVI. yüzyıldan beri Fransa'nın etki alanı olarak görülen Suriye'de 1800-1850 yılları arasında ticaret hacmini 8 kat artırmış ve böylece Suriye çölündeki bedevîlere Lancashire pamuğundan yapılmış gömlekler giydirmişti. ${ }^{55}$

Şam'da dokumacılık ve mensucât sanayi yoğun İngiliz malları ithalatından evvel epeyce gelişmişti. XIX. asrın ikinci çeyreğine doğru İngiliz imalatı yerli imalatın yerini almış vaziyetteydi. ${ }^{56} 1850$ 'de Şam'da tüketilen yün ipliğinin tamamı İngiliz malıyd. ${ }^{57}$ Pamuk ve ipek ürünlerinin Osmanlı coğrafyasında en evvel bir bütün olarak imal edildiği yerler Şam, Halep, Hama ve Humus olup Bursa ve Bilecik dokumacıllı̆̆ buralardan sonra gelişmişti. ${ }^{58}$ 1861 isyanları mensucat imalatını geçici olarak durdurdu ve imalatı Halep'e kaydırd. ${ }^{59}$ Neticede orada çalışan tezgâhların sayısı 1.000 kadar arttı. 1868 Ocak ayında yalnız 800 tezgah çalışıyordu fakat senenin sonunda [Halep'teki] sayıları 3.000'e çıktı ve Mısır'daki pazarlar için dokudular. ${ }^{60}$ XVIII. yüzyılın ilk çeyreğinden itibaren Osmanlı ile Fransa ve İngiltere arasında yoğunlaşan ticaret 1863 'te adı geçen iki devletin sermayesiyle BankOsmanî-i Şâhâne'nin tesisini doğurmuş ve artık imparatorluktaki para basma tekeli bu kuruma devredilmiştir. ${ }^{61}$

Şam, Mekke'nin Kapısı sayıldığından ${ }^{62}$ şehrin kalkınmasında hac önemli bir amil olmuştur. Nitekim, ağırlıklı genişlemenin bu güzergâh üzerinde gerçekleştiği, yüzyıllar arası

\footnotetext{
49 Inalcık Osmanlı Imparatorluğunun Ekonomik ve Sosyal Tarihi, 2/938

50 Özveren "Beyrut" Keyder, Özveren, Quataert (Ed.) Doğu Akdeniz'de Liman Kentleri, 78.

51 İnalcık Osmanlı Imparatorluğunun Ekonomik ve Sosyal Tarihi, 957.

52 Mackhintosh, Damascus and Its People,4.

53 H. Kemal Karpat,() İslam'ın Siyasallaşması, İstanbul Bilgi Üniversitesi Yayınları, İstanbul, 2009, 186.

54 inalcık, Osmanlı Imparatorluğunun Ekonomik ve Sosyal Tarihi, 2006: 957.

${ }^{55}$ Albert Hourani, Arap Halkları Tarihi, Çev. Yavuz Alogan, Illetişim Yayınları, İstanbul, 1997, 318.

56 Kinnear, Cairo, Petra and Damascus in 1839, 282.

57 Issawi, The Fertile Crescent 1800-1914, 383.

58 Süleyman Sûdî, Defter-i Muktesid, Haz. Mehmet Ali Ünal (Osmanlı Vergi Düzeni adıyla) Fakülte Kitabevi, Isparta, 2008, 246. Issawi, üretilen ipek ve pamuğun tüm Osmanlı topraklarına ihraç edildiğini kaydeder. Issawi The Fertile Crescent 1800-1914, 159.

59 Şam'ın karışan sosyal hayatında militan ustabaşılar için bkz. Sherry Vatter, "Militant Journeymen in Nineteeth-Century Damascus: Implication for the Middle Eastern Labor History Agenda" (1-21) Worker and Working Clases in the Middle East, Zachary Lockman (ed.) 1994 State University of New York

60 inalcık Osmanlı Imparatorluğunun Ekonomik ve Sosyal Tarihi, 1036.

61 Inalcık Osmanlı Imparatorluğunun Ekonomik ve Sosyal Tarihi, 1085.

62 Porter, Five Years in Damascus of the History, Topography and Antiquities of That City, I/147.
} 
farklı kent planları mukayese edildiğinde rahatlıkla görülmektedir. Hacı adaylarını ağırlayan şehirde, mevcut 300 kadar caminin çoğu gayet geniş, güzel ve zengindi. Zira camilere pek çok gelir bağışlanmıştı. ${ }^{63} 1837$ senesinde karayolu ile yapılan hac ve surre kafilesi, ${ }^{64}$ gidişte toplam 54 menzilde konaklamış ve o yıl Şam'da 31 gün kalmıştı. Kafile, dönüşte ise kentte 17 gün geçirmişti. Gidiş yolunda çok kalınması Ramazan ayının burada geçirilmesinden kaynaklanmıştı ki bu bir adetti. Menzillerde kalınan gün sayısı gidişte 58, dönüşte 32 gün olmak üzere toplam 90 gündü. ${ }^{65}$ Buna göre kafile, bütün bir hac yolculuğunun yarıdan fazlasını (48 gün) Şam'da geçirmişti ki bu hareketlilik şehre hem periyodik hem de verimli, muazzam bir katkı sunuyordu.

Hac kervanının koordine ve güvenliği, merkezileşme çabalarının bir uzantısı olarak Hac Emiri sıfatıyla Şam valisine aitti. ${ }^{66} 1708$ 'den itibaren Şam valileri yaklaşık 20.000-60.000 arası hacı adayının sevk ve idaresinde bu sıfatla sorumlu oldular. ${ }^{67}$ Fakat 1869 Süveyş Kanalı'nın açılmasından sonra Şam yolunu kullanan hacı adayları epeyce azaldı ve çok büyük bir kısmı deniz yolunu tercih etti. ${ }^{68}$ Kâbe'ye gönderilen sultan armağanlarına eşlik eden resmi Osmanlı heyeti bile dönüşte deniz güzergâhını kullanmaya başladı. Bir misal vermek lazımsa 1882 yılında sadece 4.000 hacı adayı Şam karayolunu kullanmıştı. ${ }^{69}$ Deniz yoluna rağbetin artması, daha hılı olması kadar kara kervanının bedevi kabilelerce basılması endişesinden de kaynaklanmış olmalıdır. Zira bu kervanların basılması nadir değildi. $^{70}$

\section{Demografik mozaik, çalkantılar, hastalıklar}

Raymond, Şam nüfusu için XVI. asrın başında 52.000 rakamını verirken Barkan, şehrin Müslüman nüfusunu 1569 senesinde 57.397 olarak tespit etmiştir. ${ }^{71} 1800$ 'lere doğru 313 hektarlık bir alanda ${ }^{72}$ yaklaşık $90.000,{ }^{73} 1877$ senesi için ise 202.000 şeklinde veriler

\footnotetext{
63 Porter, Five Years in Damascus of the History, Topography and Antiquities of That City, I/141.

${ }^{64}$ XIX. yy. Surre teşkilatı ve uygulamaları için bkz. Fatma Soydemir (2007), "Surre Defterlerine Göre Sultan II. Mahmut Han Vakfından Hac Yolu ve Hicaza Dağıtılan Yardımlar" (Yüksek Lisans Tezi), İstanbul: Marmara Üniversitesi.

${ }^{65}$ Münir Atalar, "Hac Yolu Güzergahı ve Masrafı (Kara Yolu, 1253/1837)” OTAM-Ankara Üniversitesi Osmanlı Tarihi Araştırma ve Uygulama Merkezi Dergisi, 1990, Sayı: 4, 45-46.

66 Yasemin Avcı, Değişim Sürecinde Bir Osmanlı Kenti: Kudüs (1890-1914), Phoenix Yayınevi, Ankara, 2004, 44; Orhonlu, Osmanlı Imparatorluğunda Derbent Teşkilatı, 25.

67 Raymond, Osmanlı Dönemi Arap Kentleri, 21. Hacı sayısının XIX. asır için 70.000-90.000 olduğu da kaydedilmiştir. Bkz. Sinan Kuneralp, “Osmanlı Dönemindeki(1831-1911) Hicazda Hac ve Kolera” Münir Atalar (Çev.) OTAM-Ankara Üniversitesi Osmanlı Tarihi Araştırma ve Uygulama Merkezi Dergisi, 1996, Sayı: 7, 500. Her sene ortalama 45.000 hacının 48 gün boyunca alışveriş ve ikamet için kaldığı şehirde, o zamanki nüfus 90.000'den fazla- göz önüne alınırsa kent yoğunluğunun en az \%50 arttığını görmekteyiz.

${ }^{68}$ Mackintosh, Damascus and Its People, 40.

69 Kuneralp “Osmanlı Dönemindeki(1831-1911) Hicazda Hac ve Kolera”, 498.

70 Raymond, Osmanlı Dönemi Arap Kentleri, 22; Orhonlu, Osmanlı Imparatorluğunda Derbent Teşkilatı, 25.

71 Ömer Lütfi, Barkan, "Tarihi demografi araştırmaları ve Osmanlı Tarihi" Türkiyat Mecmuası, 1953, Cilt 10, 1$25,19)$ Ayrıca bkz. Yunus Koç, () “Osmanlı Imparatorluğunun Nüfus Yapısı (1300-1900)” Osmanlı, Güler Eren (ed.) İstanbul, 1999, IV. 535-550

72 Raymond, Osmanlı Dönemi Arap Kentleri, 37.

73 Raymond, Osmanlı Dönemi Arap Kentleri, 29.
} 
kaydedilmiştir. $^{74} 1844$ sayımına göre bütün imparatorluk sınırlarında 150.000 Yahudî yaşamaktayken, ${ }^{75}$ kentte 1855 'te 4.630 Yahudî ve 14.005 Hıristiyan yaşamaktaydı. ${ }^{76}$ Şam'da 1860 'ta 4.000 Yahudî vardı. ${ }^{77}$ Yine aynı yıl için Şam'da mukim 22.000 Hiristiyan olduğu kaydedilmiştir. $^{78} 1882$ 'te ise 5.000-6.000 Yahudî $^{79}$ ve pek çok guruba ayrılmakla birlikte yaklaşık 20.000 Hiristiyan olduğu bilinmektedir. ${ }^{80} 1860$ 'tan 1882 'ye kadar Hiristiyan nüfustaki 2.000 kişilik azalışın sebebi, 1860 ve sonrası yaşanan şiddet olayları ve hastalıklar neticesi, çoğunlukla Beyrut'a yapılan göçler olmalıdır. Ayrıca kentte yaşayan yabancı, köle, asker ve Portekizlilerin sayısı da 1855 senesi için 15.000 olarak belirtilmiştir. ${ }^{81}$

Şam'ın sosyo-kültürel yapısı XIX. yüzyıl için birçok sıkıntı ve ayrılıklara sahne olmuş, vaktiyle bir tür zenginlik adına bir arada yaşayan farklı kimlikler, sermayeci aktörlerin elinde bir savaş silahı haline gelmişti. Neticede, Avrupalı devletlerin bölgedeki azınlıkların zulme uğraması üzerinden menfaat elde etme ve nüfuz artırma gayretleri 1840 ve 1860 hadiseleri ve destekledikleri Arap milliyetçiliğiyle meyvelerini vermeye başlamıştı. 1840 Yılında Şam'da Yahudîlerin bir rahibi öldürüp kanını da ayinlerinde kullandıkları söylentisi sebebiyle şehirdeki Hıristiyanlar Yahudîlere saldırmış ve yüzlercesi katledilmişti. ${ }^{82}$ Bunun üzerine özellikle İngiltere, Osmanlı Devleti'nin Yahudî tebasını koruyamadığını iddia ederek onların hamiliğini üstlenmeye çalışmıştı. ${ }^{83} 1860$ olayları ise Cebel-i Lübnan'da bir Hıristiyan mezhep olan Marûnîler ile orada yaşayan Dürzîler arasında patlak veren ve kısa sürede çevreye dolayısıyla da Şam'a sıçrayan şiddet hareketleridir. Şöyle ki, Dürzîler zirâî bir 1slah hareketi sebebiyle kendi aralarında tamamen parçalanmış bulunan Marûnîlerin köylerini bastılar ve buraları yakıp yıktılar. ${ }^{84}$ Tanzimat'ın getirdiği yeni yükümlülükler ve özellikle de Hıristiyanlara tanınan bazı haklar, refah içinde olmalarına rağmen ${ }^{85}$ askerlik bedelini 1858 'de bile hala ödemiyor olmaları, ${ }^{86}$ Müslümanları önceden beri rahatsız etmiş

${ }^{74}$ Mutullah Sungur, “XIX. Yüzyılda Osmanlı Devletinde Nüfus ve Nüfus Sayımları” Osmanlı, Güler Eren (ed.), Yeni Türkiye Yayınları, Ankara, IV/558-566

(1999: IV/562) Osmanlı nüfusu için ayrıca bkz. Kemal Karpat,(1985) Ottoman Population 1830-1914, Demografic and Social Characteristcs, London, University of Wisconsin Press

75 Yahudi nüfusu 1893'te 184.106, 1907'de ise 253.435'e yükselmiştir. Bkz. Yunus Koç, “Osmanlı İmparatorluğunun Nüfus Yapısı (1300-1900)" Osmanlı, Güler Eren (ed.) Yeni Türkiye Yayınları, Ankara, 1999, IV/547

${ }^{76}$ Porter, Five Years in Damascus of the History, Topography and Antiquities of That City, 139.

77 Raymond, Osmanlı Dönemi Arap Kentleri, 72.

78 Raymond, Age, 122.

79 Mackintosh, Damascus and its People, 41.

${ }^{80}$ Mackintosh, Age, 52.

${ }^{81}$ Porter, Five Years in Damascus of the History, Topography and Antiquities of That City, 139.

82 Geniş bilgi için bkz. Öke, Mim Kemal, Siyonizm'den Uygarlıklar Çatışmasına Filistin Sorunu, Ufuk Yay, İstanbul, 2002,

83 Işıl Işık Bostancı, "XIX. Yüzyılda Filistin (İdarî ve Sosyo-Ekonomik Vaziyet), (Doktora tezi) Elazı̆̆: Fırat Üniversitesi, 2006, 117.

${ }^{84}$ H. Lammens, "Suriye" MEB İslam Ansiklopedisi, Eskişehir, 2001, XI/63.

85 Porter, Five Years in Damascus of the History, Topography and Antiquities of That City, I/143. Porter, 1855 Şam'ında Hıristiyanların, hem servet biriktirme hem de bu servetleri sergileme-gösterme bakımından kendilerini güvende hissettiklerini fakat hoşlandıkları bu "korunma ve güvende olma" ortamını Avrupa konsolosluklarına borçlu olduklarını ifade eder.

${ }^{86}$ Issawi, The Fertile Crescent 1800-1914, 440. 
olduğundan olayların kente sıçramasıyla büyümesi bir olmuş ve pek çok Hıristiyan öldürülmüsştür. ${ }^{87}$ Aslında bütün bunlara asıl sebep olarak 1850 sonrası Hıristiyanların ticarî teşebbüs ve endüstrideki büyüyen payını, kent ticaretinin çoğunu yönetmelerini ${ }^{88}$ bununla birlikte Müslümanların ticarî alanda hareket kabiliyetinin zayıflamasını veya yetersiz hale gelmesini gösterebiliriz. ${ }^{89}$ Hıristiyan tebanın evlerinin kapılarına haç işareti çizilmesi ${ }^{90}$ ve olayların büyümesi Fransa'yı harekete geçirdi. "Sulh ve sükun tesisi ve sultana yardım" maksadıyla Fransa, 1860 Eylülünde Beyrut'a asker çıkardı. Sürecin devamında, Bab-1 Âli yabancı müdahalesini önlemek için Fuad Paşa'yı hudutsuz salâhiyetlerle derhal Suriye'ye yolladı. Katliamın büyümesi için 1800 'den fazla silah dağıtıldığı iddia edilse de ${ }^{91}$ bunun kentteki Osmanlı idaresince veya idarenin yönlendirmesiyle olduğunu söylemek, devletin Şam'da yürüttüğü politika ve reform çabalarıyla uyumlu olmadığ 1 için mümkün gözükmemektedir.

Hadiseler esnasında Şam vilayeti malî işleri tamamen felce uğradı. Çünkü bu görevler neredeyse bütünüyle Hıristiyanların elindeydi. ${ }^{92}$ Anlaşıldığı kadarıyla Şam'da Dürzîler ve bazı Müslümanlar, Hıristiyanlar aleyhinde ittifak yapmıştı. Bunu gören Fuad Paşa'nın kitle halinde yaptığı idamlar ve aldığı sert önlemler, Dürzî ve Müslüman çete reislerinin sürgüne gönderilmesi ve İngiltere'nin Fransa'ya duyduğu itimatsızlık neticesi Fransa daha ileri gidememiştir. ${ }^{93} 1861$ senesine gelindiğinde yaşananlar sonucunda İstanbul'da Avrupalı devletlerce Hıristiyanların güvenliğini temin etmek üzere bir konferans yapılmıştır. $\mathrm{Bu}$ konferans kararıyla da "Lübnan Mutasarrıflı̆̆ı" kurulmuştur.

Amerikalı bir misyonere göre olaylar sonrası yeni reformlarla birlikte Şam'lı Müslümanların üstünlük gururu kırıldı. Asker alımı; Müslüman şehir ve köylerin anormal borçlanması, askeri garnizonların artması ve beledî hizmetlere geçilmesi ile birlikte Müslümanların yerli Hıristiyan ve yabancılara karşı muhalefetinin tonu yumuşadı. Hıristiyan okulların sayısı katlandı. Erkekler ve hatta kızlar için açılan Türk okulları öğrencilerle doldu. Gazeteler yayınlanmaya ve okunmaya başlandı ve Hıristiyanlarla dostça bir ilişki gelişti. ${ }^{94}$

XIX. yüzyılın son çeyreğine 202.000 nüfusla giren şehrin peşini, kıtlık olmasa da hastalık bırakmadı. Osmanlı topraklarında XIX. yüzyılın ilk çeyreğinde veba, sarı humma,

\footnotetext{
871860 olayları ile ilgili mukayese için bkz. François Lenormant, Histoire Des Massacres De Syrieen 1860, Libraire De L. Hachette Et C, Paris, 1861.

88 Porter, Five Years in Damascus of the History, Topography and Antiquities of That City, 142-143.

${ }^{89}$ Elimde Şam'a dair veri olmamakla beraber imparatorluğun genelini ilgilendiren şu notu paylaşabilirim: Artan dış ticaretle birlikte (...) 1806'da Avrupa Tüccarı adı ile ayrı ve yeni bir imtiyazlı tüccar gurubu halinde organize etme kararı verildi. Böylece sarrafların maliye-iltizam sektörüne bir de dış ticaret sektörü eklenmiş oluyordu. Ama (...) aynı imtiyazlar ısrarlı taleplerine rağmen Müslüman tüccarlara uzun süre tanınmamıştır. Mehmet Genç, Osmanlı Imparatorluğunda Devlet ve Ekonomi, Ötüken Yay. İstanbul, 2002, 85.

9035 Mart 1861 Şam’ın Meydan ve Kanavat mahallelerinde görülen bu olayın ertesinde yapılan soruşturma sonuç vermedi. Vali ve Müşir bunun Hıristiyanlar tarafından yapıldığı kanaatindeydi. Nakleden: Baktıaya , “19. Yüzyıl Suriye'sinde Müslüman Hıristiyan Illişkilerinde Değişim”, 38, dip:16

${ }^{91}$ Lenormant, Histoire Des Massacres De Syrieen 1860, 100.

92 Baktıaya , "19. Yüzyıl Suriye'sinde Müslüman Hıristiyan Illişkilerinde Değişim”, 33.

93 Lammens "Suriye", 63.

94 Adil Baktıaya, "19. Yüzyıl Suriye’sinde Müslüman Hıristiyan Illişkilerinde Değişim”, Istanbul Üniversitesi iktisat Fakültesi Mecmuası, 2008, Cilt 58, Sayı 2, 38.
} 
ve kolera yaygındı. 1850 yılına kadar "hıyarcıklı veba" her beş on yılda bir Mısır, Suriye ve Arap eyaletlerinde baş gösterdi. ${ }^{95} 1826$ ' da Şam civarında veba salgını vardı. ${ }^{96}$ İmparatorluğa Rusya'dan giren kolera ise 1821 'de ilk olarak Irak'a sirayet etti ve oradan Suriye bölgesine geçti. ${ }^{97}$ Kolera sebebiyle pek çok kişi Şam'1 terk ederek yaşanabilir başka yerler aradı. ${ }^{98}$ Panikle ortaya çıkan yer değiştirme çabası salgının etki alanını genişletmiş olmalıdır. 1846'da Hicazdaki salgın sırasında hac dönüşü Osmanlı heyeti Şam yolunda koleradan ölmüşlerdi. ${ }^{99} 1848$ 'de ikinci kolera salgını ortaya çıktı. ${ }^{100}$ İngiliz tarihçi Thomas Buckle'ın 29 Mayıs 1862 'de Şam'da tifodan ölmesi ${ }^{101}$ bu tarihlerde küçük çaplı bir tifo salgının varlığını ima etmektedir. 1890'ların başında birçok Osmanlı kentini etkileyen bir yıl sonra ise Şam'a ulaşan yeni kolera salgını ${ }^{102}$ ise kentte hayatı felce uğratmıştı. ${ }^{103}$

\section{Sermaye Nesiller: Misyonerlik ve Milliyetçilik}

Şam’daki medreseler, küçük yazma kütüphaneleri de olan diğerlerine nazaran daha geniş planlanmış yapılardı. ${ }^{104}$ II. Abdülhamid döneminde kentte bir hastane ve sanat okulu açılmakla beraber ${ }^{105}$ Osmanlı kamu gücünün yabancıların kamu destekli özel eğitim yatırımlarına yetişmesi mümkün gözükmüyordu. ${ }^{106}$ Suriye, XVI. yüzyıldan itibaren Fransa'nın etki alanındaydı. XIX. yüzyılda, büyük güçlerin kendi aralarında kutsal mekânlar ve Hıristiyan azınlıklar üzerindeki etkinliklerini artırmak için giriştikleri dinî rekabet son derece açık ve serttir. Bu mücadelede Fransız Cizvitleri ve Amerikan Protestan misyonerlerinin çalışmaları dikkat çekmektedir. Bunlar, özellikle Suriye'de kolej ve çeşitli okullar açarak Arap geçmişini ve Arap mirasını bilen, bunun yanında Avrupa kültüründen de haberdar olan ve bu kültürden etkilenmiş bir Arap nesli yetiştirmeyi hedeflemişlerdir. Elbette bu çalışmalarla, hem milliyetçiliği körükleyerek bölge coğrafyasını parçalar halinde Osmanlı'dan koparma, hem de dinlerini yayma, dolayısıyla da kendi pazarlarını kurma hedefinde oldukları gizli bir bilgi değildir. ${ }^{107}$

Fransız gayretinin bir tecellisi olarak XVIII. yüzyılın ilk Fransız seyyahları, doğuya resmî vazifeyle gelmekteydi. Bu vazifeler madalyonlar, oyma taşlar, paralar aramak;

\footnotetext{
95 inalcık Osmanlı Imparatorluğunun Ekonomik ve Sosyal Tarihi, 911.

${ }^{96}$ Hamid Algar, "Hâlid el-Bağdâdî" Türkiye Diyanet Vakfı İslam Ansiklopedisi, İstanbul, 1997, XV/284

97 İnalcık, Osmanlı Imparatorluğunun Ekonomik ve Sosyal Tarihi, 911.

98 Mackintosh, Damascus and Its People, 25-26.

99 Sinan Kuneralp, “Osmanlı Dönemindeki(1831-1911) Hicazda Hac ve Kolera” Münir Atalar (Çev.) OTAMAnkara Üniversitesi Osmanlı Tarihi Araştırma ve Uygulama Merkezi Dergisi, 1996, Sayı: 7, 508

100 Porter, Five Years in Damascus of the History, Topography and Antiquities of That City, 1/138.

101 George Saintsbury, A History of Nineteenth Century Literature (1780-1895), Mac Millan and Co. New York, 1896, 243

102 Avcı Değişim Sürecinde Bir Osmanlı Kenti: Kudüs (1890-1914), 233

103 Paul Dumont, Modernleşme Sürecinde Osmanlı Kentleri, , Tarih Vakfı Yurt Yayınları, İstanbul 1996, 151.

104 Porter, Five Years in Damascus of the History, Topography and Antiquities of That City, 142.

105 Fatma Ürekli, "Tanzimat Dönemi Osmanlı Eğitim Sistemi ve Kurumları" Manas Üniversitesi Sosyal Bilimler Dergisi, 2002, Cilt 2, Sayı 3, 395.

${ }^{106}$ Aslında Osmanlının, eğitimi bir kamu görevi olarak değerlendirme iradesi Tanzimat'tan sonra görülse de bu defa da onu gerçekleştirecek "organize bir tecrübe" ve "fonksiyonel bir malî altyapı" yoksunluğu vardı.

107 Bu konuda iyi bir hulasa için bkz. Bayram Soy, (2004) "Arap Milliyetçiliği: Ortaya Çıkışından 1918’e Kadar" BiLiG, Yaz, Sayı:30 173-202.
} 
yazmalar toplamak ve böylece eski çağlar hakkındaki bilgilerin artmasına yardımcı olmakla birlikte din ve çeşitli memleketlerin adetlerinin incelenmesini kapsamaktaydı. ${ }^{108} \mathrm{Bu}$ merak elbette sadece akademik kaygıdan kaynaklanmamaktaydı. Fransa'nın gayesi, tasavvur zemininde Şam topraklarında bir "Fransız geleceği” inşa etmekti. XIX. yüzyılın sonlarına doğru daha fazla okul açılmaya başlandı. Katolik misyonerlerin açtıkları okulların yanı sıra kurdukları hastane ve yetimhaneler de vard1. Soeurs Saint Vincent Hastanesi, aynı isimde bir yetimhane Fransızlar tarafından Şam'da tesis edilmişti. ${ }^{109}$

Ruslar, 1881 yılında Petersburg'da Filistin Ortodoks Cemiyet-i Imparatoriyesi adı altında bir hayır cemiyeti kurmuşlar, bu cemiyetin ilk merkezi Nâsıra'da iken 1895'te Şam'a taşımışlardı. ${ }^{110} 1856$ yılından 1902 yılına kadar olan 46 yıllık dönemde Ruslar sadece Şam'da değil Kudüs, Beyrut ve Filistin'de de birçok hastane, okul ve kilise kurmuşlardı. ${ }^{111}$ Cizvit ve Lazaristler'in ise zaten 200 yıldan beri Şam, Halep ve Lübnan'da okulları bulunmaktaydı. Bunların temel amaçları buradaki Hıristiyanları kendi dinlerine çekmek ve teolojik kültür üzerine yoğunlaşmaktı. ${ }^{112}$

Bilindiği gibi Osmanlı topraklarında Katoliklerin hamisi Avusturya ile Fransa, Ortodokslarınki ise Rusya idi. Bunlara İngiltere de katılır ve bir Protestan topluluğu oluşturmak için çalışmalara başlar. ${ }^{113}$ İlk Protestan misyonerler kente 1843 'te yerleştiler ve İskoçya-İrlanda Presbiteryen kiliselerini açtılar. ${ }^{114}$ Bunlar, Amerikan Presbiteryenler ile beraber çok sıkı çalışıyorlardı. ${ }^{115}$ Yine İngilizler, Bâbü’ş-Şarkî’ye yakın mesafede bulunan İngiliz Suriye Okulları tarafından temsil edilmekteydi. ${ }^{116}$ Protestan misyonerler ayrıca 1853 'te liberal eğitime dayalı bir de yükseköğrenim okulu açtılar. Bunu da, erkek çocuklara Arap dilinin yanı sıra coğrafya, aritmetik ve İngiliz dili öğretilen bir ilköğretim ile ilişkilendirdiler ve desteklediler. Yüksek öğretim kurumunda ve ilköğretimde toplam 50 talebe vardı. ${ }^{117}$ Suriye valisi Nazım Bey de merkeze çektiği 6 Aralık 1898 (4 Kanunu Evvel 314) tarihli telgrafta öncelikle Müslüman halktan tenâsür eden (din değiştiren, Hıristiyan olan) bulunmadığını ancak Şam sancağının bazı kısımlarında bir İngiliz misyonerin doktor

\footnotetext{
108 Sema Çiğdemoğlu, "Ortaçağ XVI, XVII, XVIII ve XIX Yüzyıllarda Fransız Doğu Seyyahlarına Kısa Bir Bakış" Ankara Üniversitesi Dil ve Tarih-Coğrafya Fakültesi Dergisi Cilt: 38 Sayı: 12 1942, Sayfa: 111.

${ }^{109}$ Ebru Esenkal "Yabancı Ülkeler Tarafından Osmanlı Coğrafyasında Açılan Okullar." (Yüksek lisans Tezi) Edirne:

Trakya Üniversitesi, 2007, 18.

110 Esenkal, Age, 40

111 Esenkal, Age, 94

112 Bayram Soy, “Arap Milliyetçiliği Ortaya Çıkışından 1918'e Kadar” BiLiG, 2004, Yaz, Sayı:30 179.

113 Ayten Sezer, "Osmanlıdan Cumhuriyete Misyonerlerin Türkiye'deki Eğitim Öğretim Faaliyetleri” Hacettepe Üniversitesi Edebiyat Fakültesi Dergisi. 1999, Özel Sayı 173.

114 Porter, Five Years in Damascus of the History, Topography and Antiquities of That City, 146.

115 Bassam Tibî, Amerikan ve Rus misyoner okullarının siyasî bir hedefi olmadığını, ancak Fransızların tamamen kolonyal hedeflerle hareket ettiklerini söylemektedir. Buna rağmen, ilk Arap milliyetçilerinin Fransız okullarından değil, Amerikan okullarından çıktığını, bunun sebebi olarak da Amerikan okullarında Arap kültürü ve Arap dilinin üzerinde durulmasını göstermektedir. Çünkü Amerikalılar Protestan'dı ve Protestanlık'ta ibadet ana dilde yapılmaktaydı. Bundan dolayı İncil Arapça'ya çevrilmiş ve Arap dil ve kültürüne önem verilmiştir. Nakleden, Soy (2004: 193)

116 Mackintosh, Damascus and Its People, 8.

117 Porter, Five Years in Damascus of the History, Topography and Antiquities of That City, l/145-146.
} 
olarak çalışmakta olduğunu ifade etmiş ve bu doktorun Müslüman ve gayrimüslim halka dini konuları içeren bazı bilgileri yazdığı reçetelerle verdiğini kaydetmiştir. ${ }^{18}$

Defter-i Muktesid'de geçtiğine göre ise Şam-1 şerifte Rum Ortodoks Manastırının malı mikdâr-1 rüûsu 2.295 mikdâr-1 bedeli 8.032; Rum Katolik Manastırının malı mikdâr-1 rüûsu 945 mikdâr-1 bedeli 3.307; Süryânî Katolik Manastırının malı ise miksâr-1 rüûsu 200 mikdâr-1 bedeli de 700'dür. ${ }^{119}$ Bu veriler Rusların çalışmalarının yoğun ve verimli olduğuna işaret sayılabilir. Zira Rum Ortodokslar onların himayesindeydi. ${ }^{120} 1860$ sonrası Hıristiyan okulların sayısı en az ikiye katlanmıştı. ${ }^{121}$ Zira Fransa, Avusturya ve Rusya Müslümanlarla Hıristiyanlar arasındaki olaylardan yararlanıp Katolik ve Ortodoksları himaye etme bahanesiyle bölgedeki nüfuzlarını artırmışlardı.

XIX. yüzyılda Avrupa'da gelişen milliyetçilik akımlarının ortak özelliklerinin etkisinde bir Arap milliyetçiliği oluşurken, Arabistan'da, XVIII. yüzyılın ikinci yarısında vuku bulan Vehhabi ayaklanması örneğinde olduğu gibi, farklı dinî yaklaşımlarla veya merkez otoriteye isyan şeklinde kabîleci bir milliyetçilik anlayışı gelişmiş̧tir. Misyonerlerin inşasına çalıştıkları sosyal kimliğin kolayca belirginleşmesi, keskinleşmesi ve kendi amaçlarına hizmet etmesi için en güzel zemin milliyetçilikti. Bu sebeple misyonerler bu süreçte çoğu vakit karşımıza samimi ve koyu birer Arap milliyetçiliği müdafii olarak çıktılar. Arap kültürünün ve Arap dilinin, ümmet anlayışı elinde heba olduğunu ve çok daha asil bir yere sahip olduğunu vurguladılar. Tabiatıyla, bu şartlar altında gelişen Arap milliyetçiliği, özellikle Hıristiyan Araplar arasında daha da yaygınlaşmıştır. Milliyetçilik hareketlerinin gelişimi, 1882'de İngiltere'nin Arap dünyasının merkezi olan Mısır'ı işgal etmesiyle, yani Mısır'ın doğrudan Avrupa'nın etkisi altına girmesiyle daha da hızlanmıştır. ${ }^{122}$

\section{Sonuç Yerine}

Çok kültürlülüğün arz-1 endam ettiği Ortadoğu'nun nadide şehirlerden biri olan Şam, Osmanlı'nın en uzun yüzyılı sayılan XIX. yüzyılda pek çok badireler atlattı. Burada birlikte yaşama anlayışının en büyük zafiyeti, darlık ve buhran süreçlerinin ayrıştırıcı tesirine çabuk kapılmasıydı. $\mathrm{Bu}$ ayrışma ve dağılma XIX. asırda şehirde fazlasıyla hissedilmişti. İmparatorluğun ardı ardına gelen idarî ve imarî toparlanma çabalarının, bir o kadar ters akisleri, siyasi ve içtimaî sahada Şam'da yaşanmıştı. Hastalıklarla neredeyse her on yılda bir boğuşan şehir, bir yandan zamana yayılan şiddet olaylarıyla örülmüş diğer yandan, Süveyş Kanalı'nın açılmasıyla hem ticaret hem de hac ağından elde ettiği kar ve kazancı hissedilir şekilde kaybetmişti. 1840 ve 1860 olaylarıyla yaşanan talihsizlikler bazı Hıristiyanlar için göçü de beraberinde getirmişti. Şehrin ticaretine önemli ölçüde İngiliz malları hakim olsa da bu göz kamaştıran pazarı Fransa ile paylaşmaktaydı. Yüzyıl boyunca genişleme dışında

\footnotetext{
118 Ebru Esenkal, "Yabancı ülkeler tarafından Osmanlı coğrafyasında açılan okullar." (Yüksek lisans Tezi) Edirne: Trakya Üniversitesi, 2007, 48.

119 Süleyman Sûdî, Defter-i Muktesid, Mehmet Ali Ünal (Osmanlı Vergi Düzeni adıyla Haz.), Fakülte Kitabevi, Isparta, 2008, 178.

120 Rusya'nın, bugün dahi (Kasım 2012) malum olan Şam ilgisi, bu devletin, bölge coğrafyası ve sıcak denizler sevdasının payidar kaldığına işaret etmektedir.

121 Baktıaya, "19. Yüzyıl Suriye'sinde Müslüman Hıristiyan Illişkilerinde Değişim”, 38.

122 Bayram Soy, “Arap Milliyetçiliği Ortaya Çıkışından 1918'e Kadar” BiLiG, 2004, Yaz, Sayı:30 177.
} 
merkezî plan fotoğrafinda çok değişme olmamıştı. Hac güzergâhına doğru genişleyen şehir silüeti; dar sokakları, çarşı ve hanlarıyla klasik bir Şark-İslam şehrini andırsa da zayıflayan ve her yere yetişemeyen irade-i seniyyenin buradaki eğitim boşluğunu Katolik, Ortodoks ve Protestan misyonerler doldurmuş ve pek çok kurum açmışlardı.

Şam, XIX. yüzyılda, değiş̧en yollar, misyonerlerin hünerli ve dost ellerinde daha yenice yeşeren Arap milliyetçiliği, azınlık hakları, bozulan sosyal düzen ve idarî karmaşa arasında kent olarak var olma mücadelesi vermişti. Aslında bütün bir asır yaşananların tablosu bize, Şam ufuklarındaki Osmanlı güneşinin son gurûb hikâyesini sunmakta ve kentin semalarının, yeryüzünde kopan firtınanın aksine, Devlet-i Aliyye'ye sessiz sedasız veda edişini resmetmekteydi.

\section{KAYNAKÇA}

Algar, Hamid, (1997) "Hâlid el-Bağdâdî" İslam Ansiklopedisi, XLI Cilt, İstanbul, Türkiye Diyanet Vakfi, XV. 283-285.

Atalar, Münir, (1990) Hac Yolu Güzergahı ve Masrafı (Kara Yolu, 1253/1837) OTAMAnkara Üniversitesi Osmanlı Tarihi Araştırma ve Uygulama Merkezi Dergisi, Sayı: 4, 43-74.

Avcı, Yasemin, (2004) Değişim Sürecinde Bir Osmanlı Kenti: Kudüs (1890-1914), Ankara, Phoenix Yayınevi.

Baalbâki Münir (with Rûhî, 1998) Al-Mavrid Dictionary, English-Arabic-Arabic-English, Beyrut, Dâru'l-ìlm Lilmalâyîn.

Baktıaya, Adil (2008) "19. Yüzyıl Suriye'sinde Müslüman Hıristiyan ilişkilerinde değişim.” İstanbul Üniversitesi İktisat Fakültesi Mecmuası, Cilt 58, Sayı 2, 23-44.

Barkan, Ömer Lütfi, (1953) "Tarihi demografi araştırmaları ve Osmanlı Tarihi” Türkiyat Mecmuast, Cilt 10, 1-25.

Bostanc1, Iş̧1 Işsk, (2006) "XIX. Yüzyılda Filistin (İdarî ve Sosyo-Ekonomik Vaziyet), (Doktora tezi) Elazığ: Firat Üniversitesi.

Buzpınar, Şit Tufan, (2010) “Şam” İslam Ansiklopedisi, XLI Cilt, İstanbul, Türkiye Diyanet Vakfi, XXXVIII. 311-320.

Çiğdemoğlu, Sema, (1942) “Ortaçağ XVI, XVII, XVIII ve XIX Yüzyıllarda Fransız Doğu Seyyahlarına Kısa Bir Bakış" Ankara Üniversitesi Dil ve Tarih-Coğrafya Fakültesi Dergisi Cilt: 38 Say1: 12 Sayfa: 104-120.

Daskalakis, Annie-Christine Mathews, "A Room of Splendor and Generosty from Ottoman Damascus", İnstitute of Arts, New York Universty, Metropolitan Museum Journal 32, 1997, 111-139.

Dumont, Paul, (1996) Modernleşme Sürecinde Osmanlı Kentleri, İstanbul, Tarih Vakfı Yurt Yayınları, 136-152. 
Esenkal, Ebru, (2007) "Yabancı ülkeler tarafından Osmanlı coğrafyasında açılan okullar." (Yüksek lisans Tezi) Edirne: Trakya Üniversitesi.

Genç, Mehmet, (2002) Osmanlı Imparatorluğunda Devlet ve Ekonomi, İstanbul, Ötüken Yay.

Hanna, Nelly, (2005) “Osmanlı Dönemi Arap Şehir Tarihi Üzerine Bir İnceleme” Türk Şehir Tarihi, Türkiye Araştırmaları Literatür Dergisi, Cilt 3 Sayı 6, İstanbul.

Hartmann, R., (2001) “Şam” İslam Ansiklopedisi, Cilt, Eskişehir, MEB Yayınları, XI, 298310.

Houranı, Albert, (1997) Arap Halkları Tarihi, (Çev. Yavuz Alogan) İstanbul, İletişim Yayınlar1.

Issaw1, Charles, (1988) The Fertile Crescent 1800-1914 A Documentary Economic History, New York, Oxford Universty Press.

İnalcık, Halil, (2006) Osmanlı Imparatorluğunun Ekonomik ve Sosyal Tarihi, (İnalc1k, Quataert ed.) İstanbul, II Cilt.

Kalkaşendî, Ahmed b. Ali, (1987) Subhu'l-A şấ fî Sınâati'l-İnşâ, XV Cilt, Beyrut, Dâru'lFikr, (IV/95-200).

Karpat, H. Kemal,(1985) Ottoman Population 1830-1914, Demografic and Social Characteristcs, London, University of Wisconsin Press.

Karpat, H. Kemal,(2009) İslam’ın Siyasallaşması, İstanbul, İstanbul Bilgi Üniversitesi Yayınları.

Kinnear, John Gardiner, (1841) Cairo, Petra and Damascus in 1839, London, John Murray, Albemarle Street.

Koç, Yunus, (1999) “Osmanlı İmparatorluğunun Nüfus Yapısı (1300-1900)” Osmanll, Güler Eren (ed.) Osmanl, XII Cilt, Ankara, Yeni Türkiye Yayınları, IV. 535-550.

Kuneralp, Sinan, (1996)“Osmanlı Dönemindeki(1831-1911) Hicazda Hac ve Kolera” Münir Atalar (Çev.)OTAM-Ankara Üniversitesi Osmanlı Tarihi Araştırma ve Uygulama Merkezi Dergisi, Say1: 7, 497-511.

Lammens, H., (2001) “Suriye” Íslam Ansiklopedisi, XV Cilt, Eskişehir, MEB yayınları, XI. 51-66.

Lenormant, Francois, (1861) Histoire Des Massacres De Syrie en 1860, Paris, Libraire De L. Hachette Et C.

Mackintosh, Mrs. (1883) Damascus and Its People, London, Seely Jackson and Halliday, Fleet Street.

Margoliouth, D.S., (1907) Cairo, Jerusalem and Damascus: Three Chief Cities of the Egyptian Sultans, New York, Dodd, Mead and Company.

Orhonlu, Cengiz, (1990) Osmanlı Imparatorluğunda Derbent Teşkilatı, İstanbul, Eren Yayınc1lik. 
Öke, Mim Kemal, (2002) Siyonizm'den Uygarlıklar Çatışmasına Filistin Sorunu, İstanbul, Ufuk yay.

Özveren, Y. Eyüp, (1994) “Beyrut” Keyder, Özveren, Quataert (Ed.) Doğu Akdeniz'de Liman Kentleri, İstanbul, Tarih Vakfı Yurt Yayınları, 75-102.

Porter, J.L. A.M.,F.R.S.L., (1855) Five Years in Damascus of the History, Topography and Antiquities of that City, Vol. II, London, I. 1-278.

Rasim, Binbaş1 Mustafa, (1305) Memâlik-i Mahrûsa-i Şâhâne Coğrafyası, Dersaâdet Tophane-i Âmire Mat.

Raymond, Andre, (1995) Osmanlı Dönemi Arap Kentleri, (Çev. Ali Berktay), İstanbul, Tarih Vakfi Yurt Yayınları.

Redhouse, James,W.(1884) A.H. Boyajian (Print.) A Lexicon English and Turkish / Lehcetü'l-Meânî, Constantinople, Third Edition.

Saintsbury, George, (1896) A History of Nineteenth Century Literature (1780-1895), New York, Mac Millan and Co. And London.

Sezer, Ayten, (1999) "Osmanlıdan Cumhuriyete Misyonerlerin Türkiye'deki Eğitim Öğretim Faaliyetleri” Hacettepe Üniversitesi Edebiyat Fakültesi Dergisi. Özel Sayı 169-183.

Soy, Bayram, (2004) “Arap Milliyetçiliği Ortaya Çıkışından 1918’e Kadar” BİLİG, Yaz, Say1:30 173-202.

Soydemir, Fatma, (2007), "Surre Defterlerine Göre Sultan II. Mahmut Han Vakfindan Hac Yolu ve Hicaza Dağıtılan Yardımlar" (Yüksek Lisans Tezi), İstanbul: Marmara Üniversitesi.

Sûdî, Süleyman, (2008) Defter-i Muktesid, Mehmet Ali Ünal (Osmanlı Vergi Düzeni adıyla Haz.) Isparta, Fakülte Kitabevi.

Sungur, Mutullah, (1999) "XIX. Yüzyılda Osmanlı Devletinde Nüfus ve Nüfus Sayımları" Güler Eren (ed.) Osmanl, XII Cilt, Ankara, Yeni Türkiye Yayınları, IV. 558-566.

Ürekli, Fatma, (2002) “Tanzimat Dönemi Osmanlı Eğitim Sistemi ve Kurumları" Manas Üniversitesi Sosyal Bilimler Dergisi, Cilt 2, Say1 3, 382-406.

Vatter, Sherry, (1994) "Militant Journeymen in Nineteeth-Century Damascus: İmplication for the Middle Eastern Labor History Agenda" Worker and Working Clases in the Middle East, Zachary Lockman (ed.), State University of New York, (1-21).

Weber, Stefan, (1999) "Ottoman Damascus of the 19th Century Artistic and Urban Development as an Expression of Changing Times" Art Turc / Turkish Art 10th International Congress of Turkish Art. Geneva, 731-740.

Zara, Lababedi,(2008) The urban development of Damascus: A Study of Its Past, Present and Future. Masters thesis, UCL (University College London). 


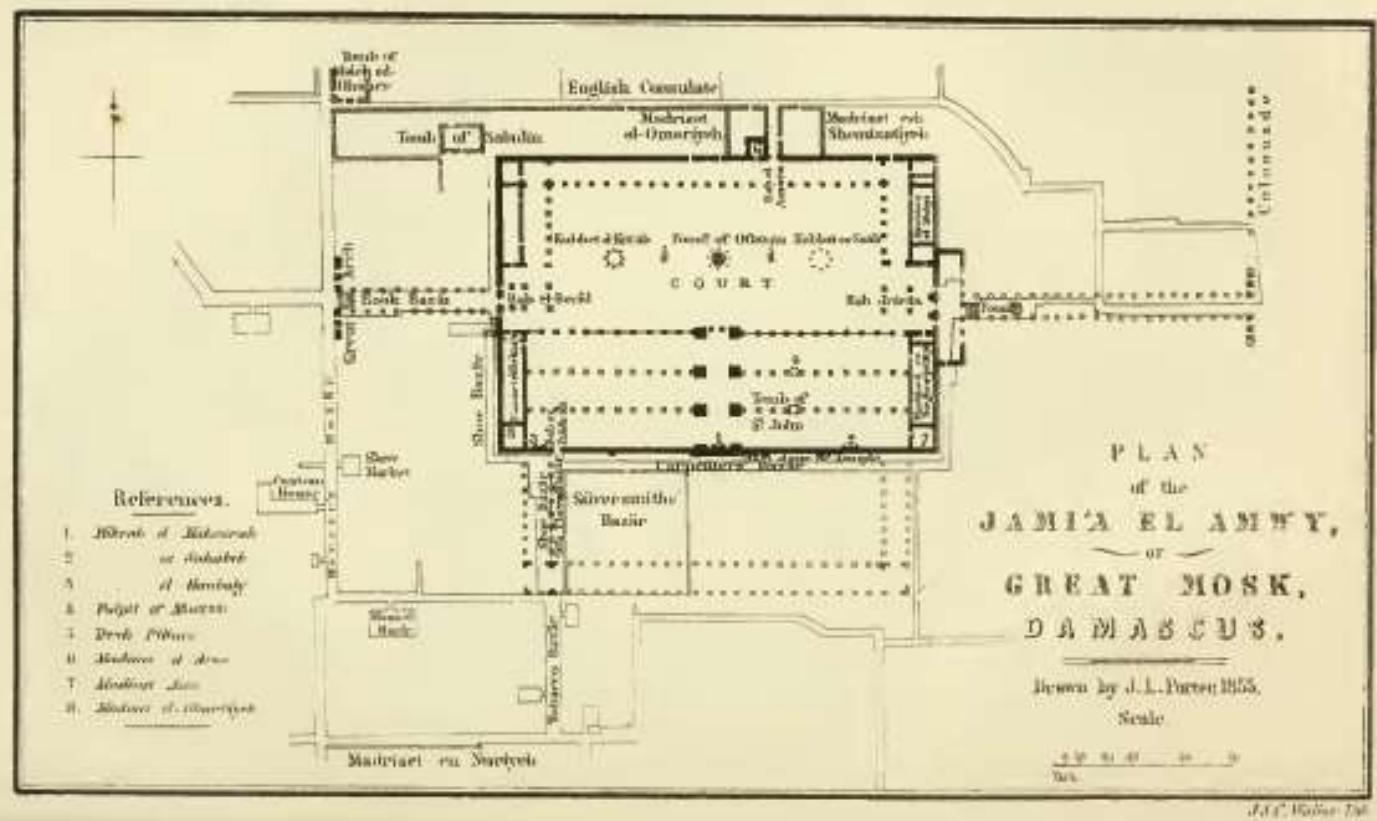

Şekil-1: Şam Ümeyye Camii ve civarındaki çarşıları gösteren plan. Porter (1855: I/61)

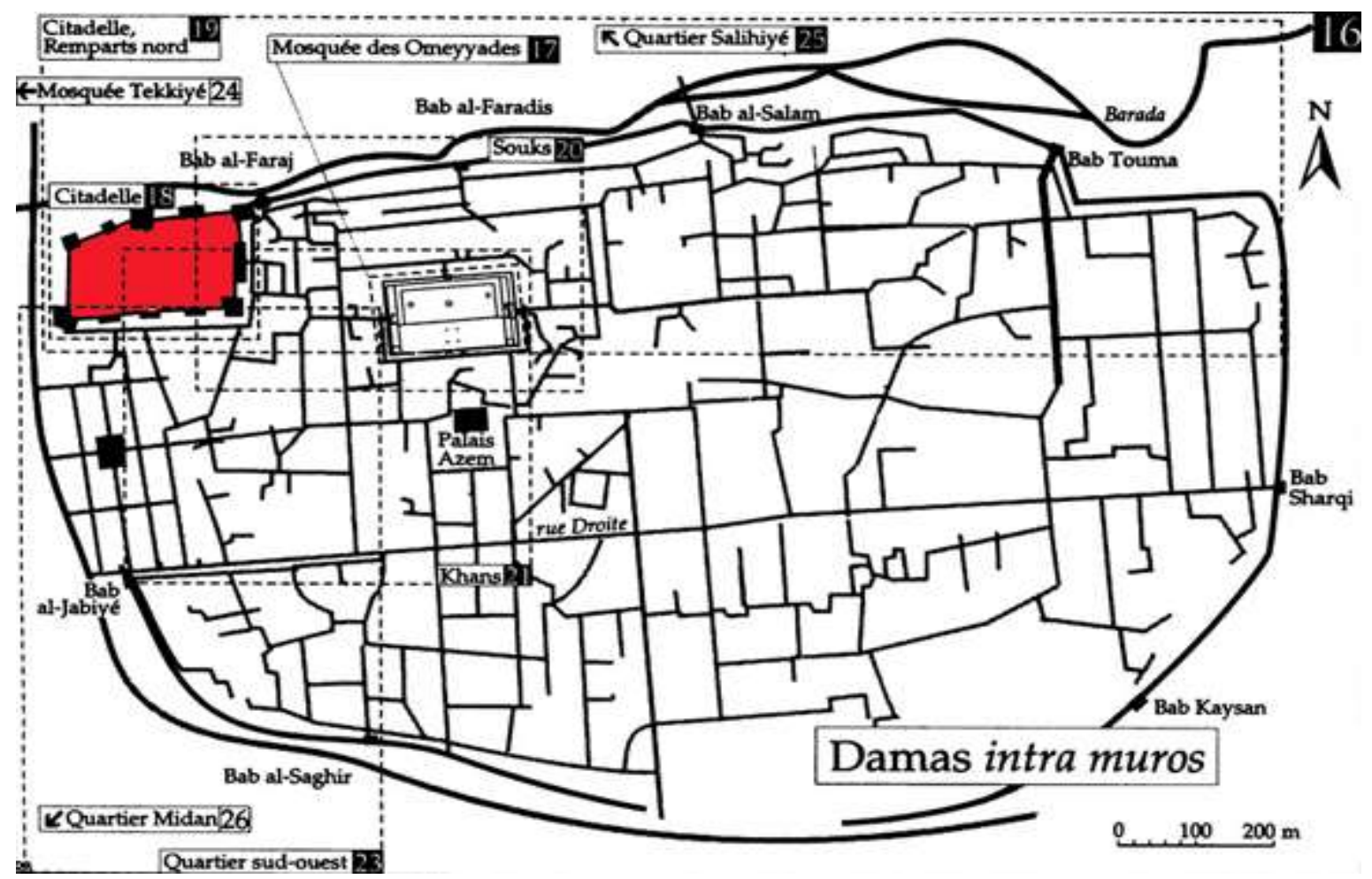

Şekil-2 Suriçi şehir planı (Erişim: 21.10.2012) http://www.diplomatie.gouv.fr/en/global-issues/educationresearch/archaeology/archaeology-notebooks/ancient-east/syria-the-citadel-of-damascus/ 


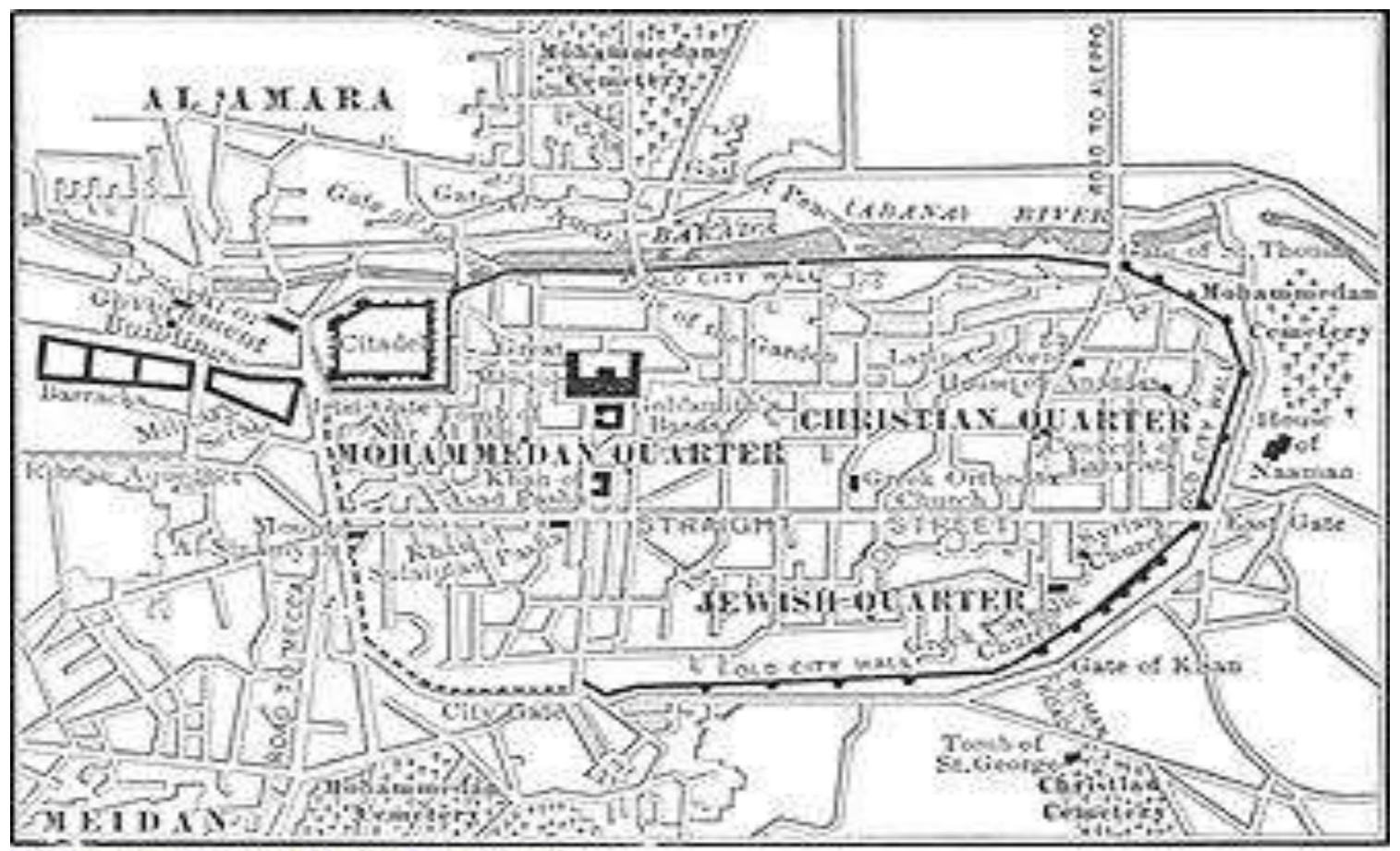

GJewishEncyclopedia.com

Şekil-3: Suriçi üç mahalle ve Aşağı Meydan başlangıcı (Erişim: 21.10.2012)

http://www.google.com.tr/imgres?q=damascus+christian+quarter+city+plan\&start=165\&hl=tr\&biw=1366\&bih=643\&tbm=isch\&tbnid=kF P0F55NbKyXpM:\&imgrefurl=http://www.jewishencyclopedia.com/articles/4861-

damascus\&docid=IG8q3ipB89zSLM\&imgurl=http://d5iam0kjo36nw.cloudfront.net/V04p417001.jpg\&w=335\&h=259\&ei=GsmWUJLENa

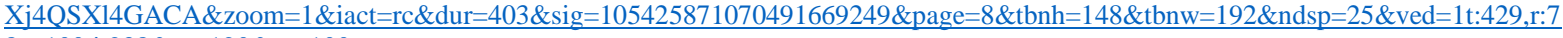
$\underline{8, \mathrm{~s}: 100, \mathrm{i}: 238 \& \mathrm{tx}=120 \& \mathrm{ty}=100}$

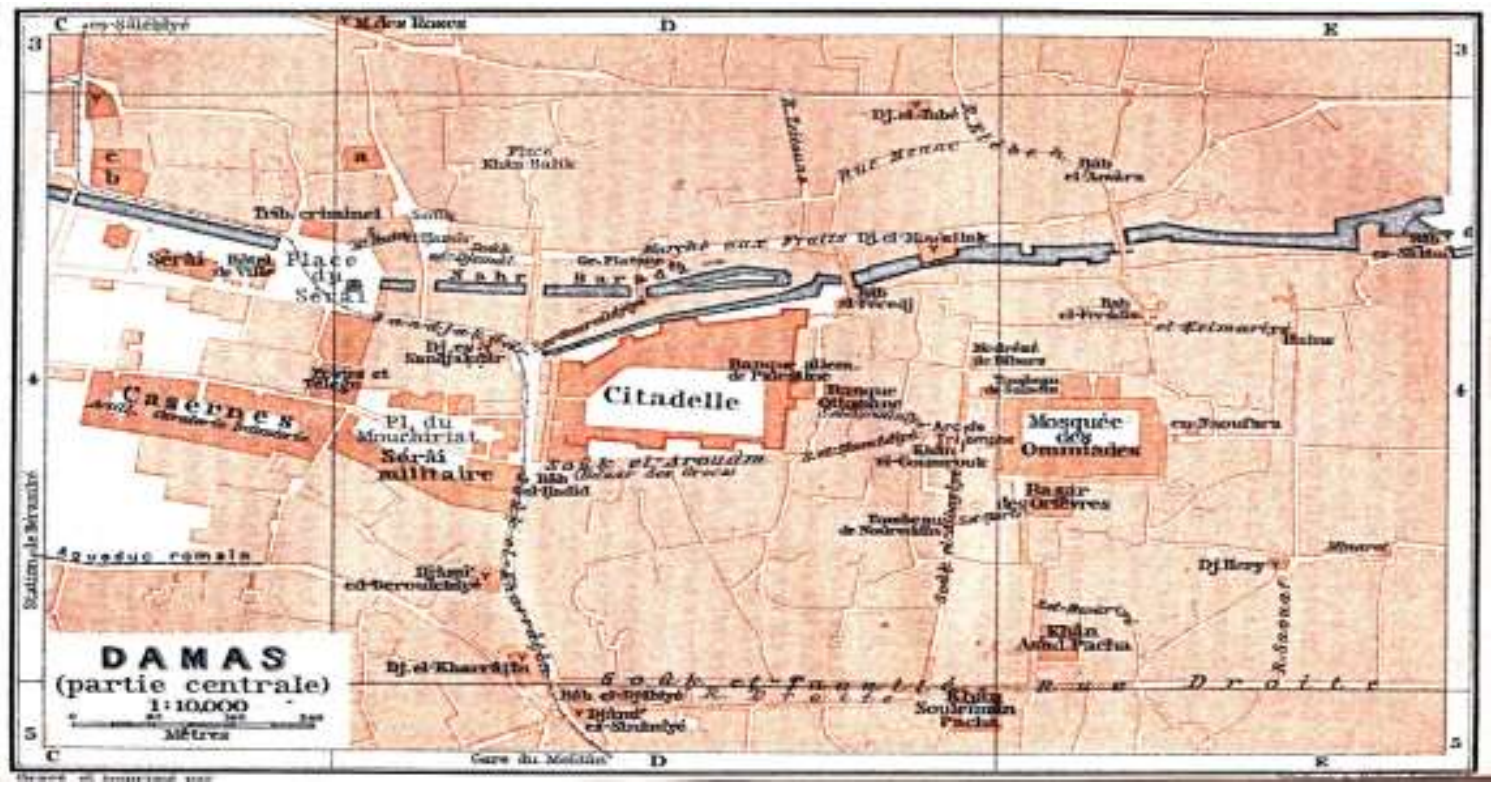

Şekil-4: Şam şehir planı 1912 (Erişim. 21.10.2012) 
http://www.orsam.org.tr/tr/trUploads/Haritalar/Images/Damascus-1912-Map.jpg

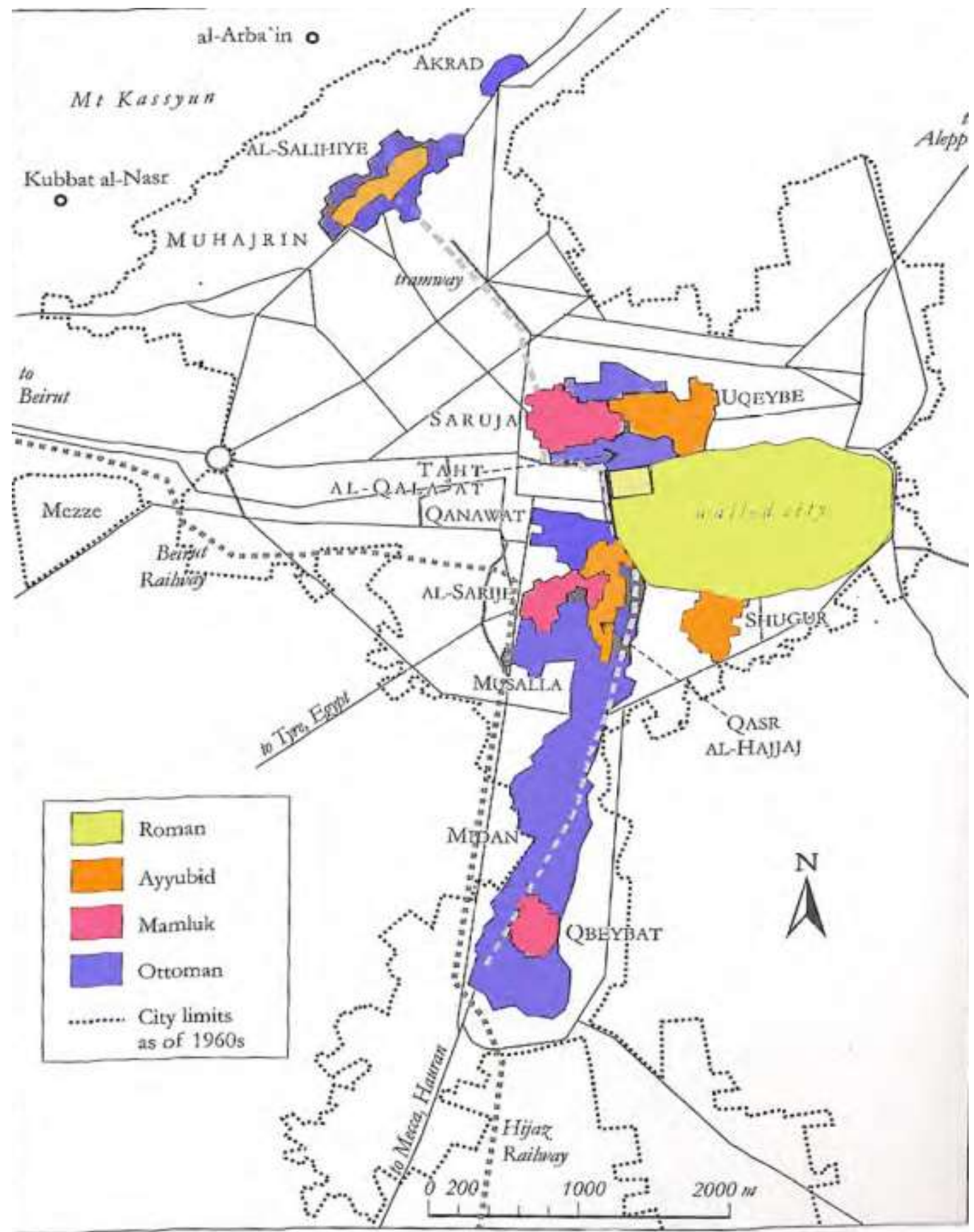

Şekil-5: Şam'ın Roma, Eyyûbi, Memlük ve Osmanlı dönemlerindeki gelişimini gösteren plan Zara Lababedi, urban development of Damascus: A Study of Its Past, Present and Future. Masters thesis, University College London. $2008,21$. 

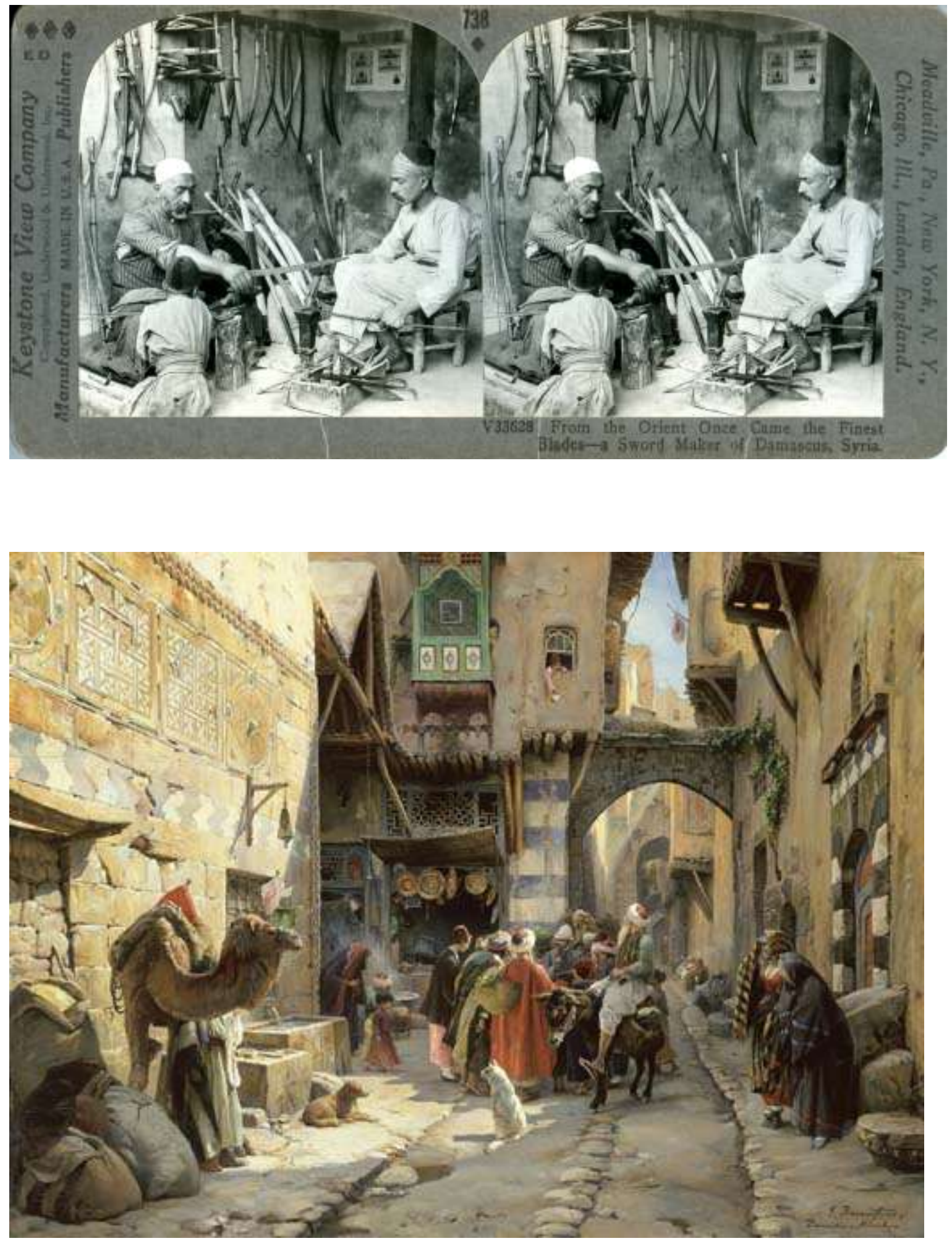

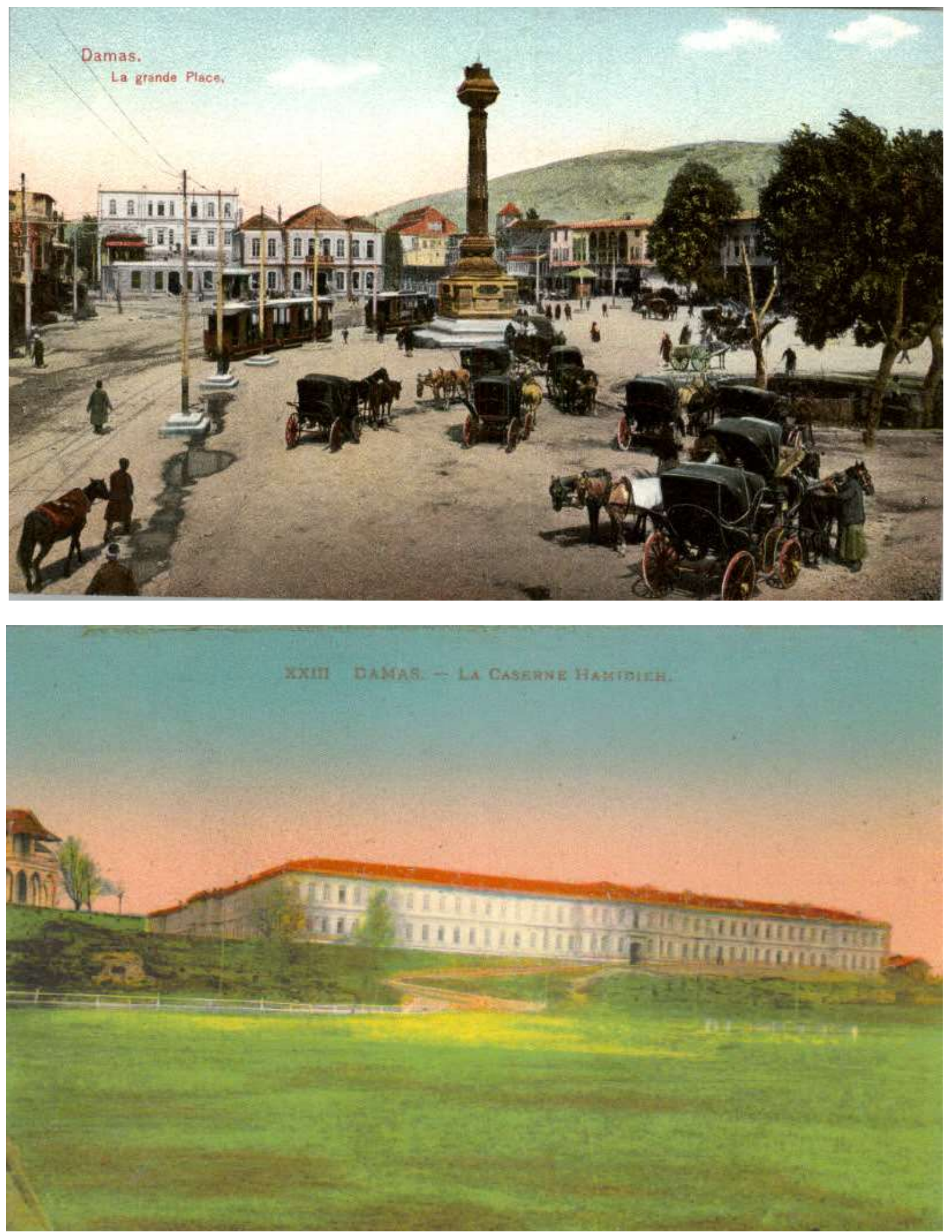


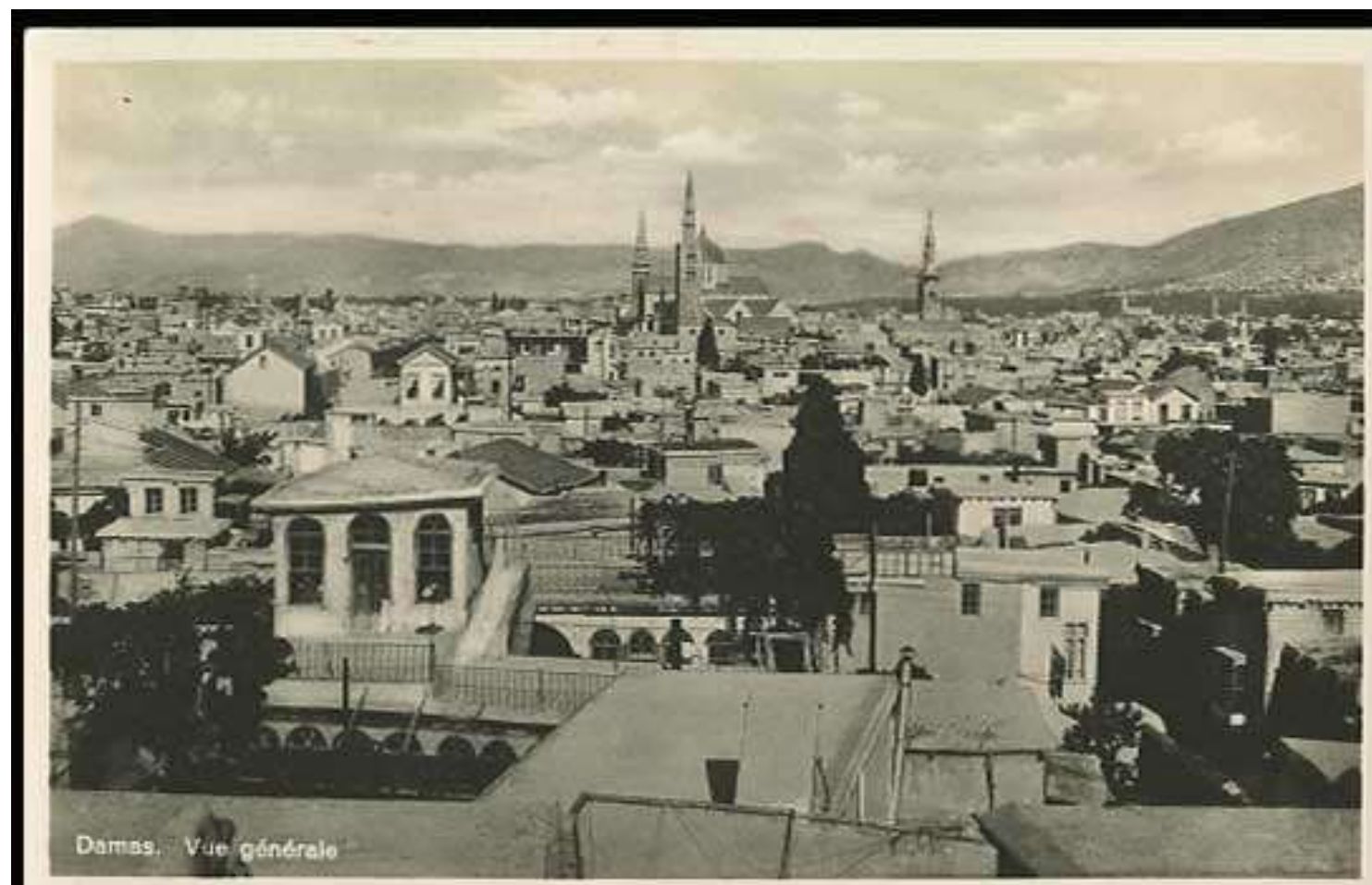

\section{CARTE POSTALE}

Correupadente 


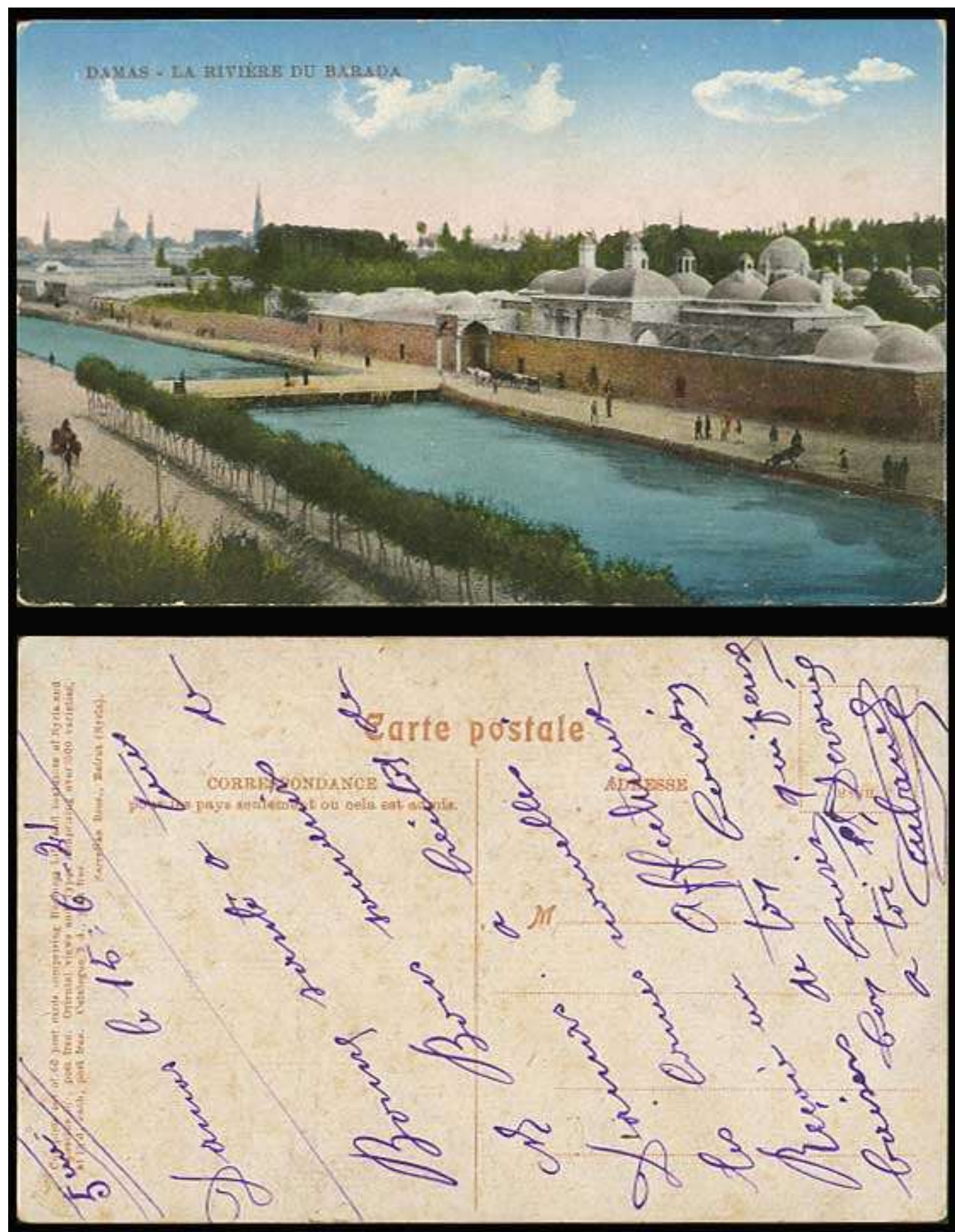

